\title{
Heterogeneity within T cell memory: implications for transplant tolerance
}

\section{Scott M. Krummey and Mandy L. Ford*}

Department of Surgery, Emory Transplant Center, Emory University, Atlanta, GA, USA

Edited by:

Xian Chang Li, Brigham and Women's Hospital, USA

\section{Reviewed by:}

Alexander G. Betz, Medical Research

Council Laboratory of Molecular

Biology, UK

Anne L. Fletcher, Dana-Farber Cancer Institute, USA

\section{*Correspondence:}

Mandy L. Ford, Department of Surgery, Emory Transplant Center, Emory University, 101 Woodruff

Circle, Suite 5105 WMB, Atlanta, GA 30322, USA.

e-mail: mandy.ford@emory.edu
Adaptive immunity in both mouse and man results in the generation of immunological memory. Memory T cells are both friend and foe to transplant recipients, as they are intimately involved and in many cases absolutely required for the maintenance of protective immunity in the face immunosuppression, yet from the evidence presented herein they clearly constitute a formidable barrier for the successful implementation of tolerance induction strategies in transplantation. This review describes the experimental evidence demonstrating the increased resistance of memory $T$ cells to many distinct tolerance induction strategies, and outlines recent advances in our knowledge of the ways in which alloreactive memory $T$ cells arise in previously untransplanted individuals. Understanding the impact of alloreactive memory $T$ cell specificity, frequency, and quality might allow for better donor selection in order to minimize the donor-reactive memory $T$ cell barrier in an individual transplant recipient, thus allowing stratification of relative risk of alloreactive memory $T$ cell mediated rejection, and conversely increase the likelihood of successful establishment of tolerance. However, further research into the molecular and cellular pathways involved in alloreactive memory $T$ cell-mediated rejection is required in order to design new strategies to overcome the memory $T$ cell barrier, without critically impairing protective immunity.

Keywords: memory T cells, transplantation tolerance, heterologous immunity, costimulation

\section{OVERVIEW OF MEMORY T CELL PROGRAMMING}

One of the hallmark features of adaptive immunity is immunologic memory. Antigen-specific $\mathrm{T}$ cells that have experienced a prior encounter with cognate antigen exist at a higher precursor frequency than they did as naïve clones, and have acquired a differentiation program that allows them to rapidly and robustly respond to subsequent encounters, usually at a lower activation threshold than their naïve counterparts (Ahmed and Gray, 1996). The last 20 years have seen an explosion in new knowledge regarding the instructional developmental programs that impart these qualities upon memory $\mathrm{T}$ cells, and most of this knowledge has come from the study of memory $\mathrm{T}$ cell differentiation in response to viral infection. It is now known that following clonal expansion and contraction of an antigen-specific $\mathrm{T}$ cell population, a heterogeneous memory pool consisting of central and effector memory populations remains. Recently, studies have focused on elucidating factors that identify short-lived effectors and memory cell precursors at very early timepoints following infection.

During the primary $\mathrm{CD}^{+}{ }^{+} \mathrm{T}$ cell response to antigen, shortlived effector cells fail to re-express CD127 and upregulate the senescence marker KLRG-1 (Kaech et al., 2003; Huster et al., 2004; Sarkar et al., 2008). Memory precursor cells upregulate CD127 and remain KLRG-1 low, although several studies have shown that CD127 is permissive but not instructive or even required for memory cell formation (Lacombe et al., 2005; Wojciechowski et al., 2006; Hand et al., 2007). After the contraction phase, $\mathrm{CD}^{+}$central memory cells are maintained in lymph tissues due to expression of CD62L and CCR7, while effector memory cells have greater cytotoxic potential and reside in peripheral tissues (Sallusto et al., 1999; Masopust et al., 2001). The transcription factors T-bet, eomesodermin, Blimp-1, and the serine kinase mTOR have been implicated in the distinct differentiation programs of long-lived $\mathrm{CD}^{+}$memory precursors as compared to short-lived effector T cells (Intlekofer et al., 2005, 2007; Joshi et al., 2007; Kallies et al., 2009; Rutishauser et al., 2009; Shin et al., 2009; Banerjee et al., 2010). Specifically, T-bet and BLIMP- 1 are thought to be critical in the differentiation and contraction of $\mathrm{CD} 8^{+}$effector $\mathrm{T}$ cell populations, as evidenced by the increased differentiation of memory $\mathrm{CD}^{+} \mathrm{T}$ cells in both $\mathrm{T}$ bet $^{-1-}$ and BLIMP ${ }^{-1-}$ animals (Intlekofer et al., 2005; Joshi et al., 2007; Kallies et al., 2009; Rutishauser et al., 2009; Shin et al., 2009; Welsh, 2009; Rao et al., 2010). In contrast, CD8 ${ }^{+} \mathrm{T}$ cells lacking eomesodermin were shown to compete poorly in differentiating into central memory cells (Araki et al., 2008; Banerjee et al., 2010; Rao et al., 2010). More specifically, eomesodermin-deficient CD8 ${ }^{+}$ T cells showed similar magnitude and kinetics of expansion following antigen priming as compared to wild-type $T$ cells, but were less able to survive long-term, were defective in establishing a memory pool in the bone marrow, and exhibited diminished secondary recall responses (Banerjee et al., 2010). Taken together, these data suggest that that T-bet and eomesodermin have reciprocal functions in terms of their abilities to promote the differentiation of short-lived effector cells versus long-lived memory precursor cells. However, the molecular mechanisms underlying the regulation of 
these transcription factors is still largely unknown and is an area of intense investigation.

$\mathrm{CD}^{+}$memory $\mathrm{T}$ cell programming has received comparably less attention than $\mathrm{CD}^{+} \mathrm{T}$ cell memory, due in part to the fact that $\mathrm{CD}^{+}{ }^{+}$memory $\mathrm{T}$ cells exist at lower frequencies than $\mathrm{CD} 8^{+}$ memory T cells (Harrington et al., 2008; Pepper et al., 2011), and that class II tetramers for the detection of polyclonal endogenous antigen-specific memory $\mathrm{T}$ cells have been developed only recently (Landais et al., 2009). However, many features of CD4 ${ }^{+}$ memory differentiation are emerging. Similar to the differentiation of $\mathrm{CD}^{+}$memory $\mathrm{T}$ cells (Wherry et al., 2003; Wherry and Ahmed, 2004), Th1 effector memory cells arise from Th1 effectors during clonal expansion (Harrington et al., 2008; Lohning et al., 2008; Sprent et al., 2008). While CD127 is also permissive for CD4 memory cell formation, the transcription factors T-bet, Blimp-1, and eomesodermin do not delineate memory CD4 cell precursors in the same way as they do for $\mathrm{CD}^{+}$memory (Yang et al., 2008; Pepper et al., 2010). However, a recent study revealed that a subset of $\mathrm{CD}^{+}{ }^{+}$cells that displayed decreased expression of Ly6C and T-bet following antigen encounter were better able to survive long-term and demonstrated superior recall responses to secondary challenge (Marshall et al., 2011). The authors of this study also compared the gene expression profiles of the population of Ly6C ${ }^{\text {lo }}$ T-bet $^{\text {int }} \mathrm{CD} 4^{+}$effector cells to that of mature memory $\mathrm{CD} 4^{+} \mathrm{T}$ cells, and found them to be virtually identical. These data suggest that $\mathrm{Ly}_{6} \mathrm{C}^{\text {lo }} \mathrm{T}^{-\mathrm{bet}}{ }^{\mathrm{int}} \mathrm{CD} 4^{+}$cells comprise a population of early maturating memory $\mathrm{CD}^{+}{ }^{+}$within the pool of effectors. In addition, two reports have shown that $\mathrm{CD} 4^{+}$central memory cells have a $\mathrm{T}$ follicular helper-like $\mathrm{CCR} 7^{+} \mathrm{CXCR}^{+}$phenotype (Chevalier et al., 2011; Pepper et al., 2011). It is these molecular changes that in part are responsible for memory $\mathrm{T}$ cells' superior functional capabilities, long life span, and reduced activation requirements upon recall as compared to their naïve counterparts (Sallusto et al., 1999).

\section{EVIDENCE FOR ALLOREACTIVITY AMONG MEMORY}

When examining the potential barrier posed by alloreactive memory $\mathrm{T}$ cells, one must first consider the evidence that alloreactivity exists within the memory $\mathrm{T}$ cell compartments of mouse and man. For at least the last two decades, there has been considerable debate concerning the relative precursor frequencies of alloreactive clones among naïve vs. memory $\mathrm{T}$ cell populations (Lombardi et al., 1990; Lechler et al., 1991). This question was first addressed by seminal studies which approached the problem by using cord blood-derived T cell preparations, which were shown to contain little to no memory T cells (Lombardi et al., 1990), and later by ELISPOT techniques to identify cells secreting cytokines in response to brief stimulation with alloantigen (Heeger et al., 1999). Because naïve $\mathrm{T}$ cells do not begin to produce cytokines until 16$24 \mathrm{~h}$ post stimulation, these early cytokine producers were deemed alloreactive memory $\mathrm{T}$ cells. However, our ability to probe these questions has matured along with the evolution of our understanding and identification of memory $\mathrm{T}$ cell phenotypes and ability to physically sort these subsets using flow cytometry. Specifically, a 2009 study which analyzed the frequencies of alloreactive T cells in naïve $\left(\mathrm{CD} 45 \mathrm{RO}^{-} \mathrm{CD}^{-} \mathrm{L}^{+}\right)$, central memory $\left(\mathrm{CD} 45 \mathrm{RO}^{+}\right.$ $\left.\mathrm{CD} 2 \mathrm{~L}^{+}\right)$, effector memory $\left(\mathrm{CD} 45 \mathrm{RO}^{+} \mathrm{CD}^{-} \mathrm{L}^{-}\right)$, and terminal effector memory $\left(\mathrm{CD} 4 \mathrm{RO}^{-} \mathrm{CD}^{-} 2 \mathrm{~L}^{-}\right)$compartments addressed this issue, and revealed that approximately equal frequencies of alloreactive T cells exist among these subsets (Macedo et al., 2009). Perhaps one reason that the frequency of alloreactivity among memory $\mathrm{T}$ cell compartments has been debated lies in the fact that there are differences in the ways in alloreactivity manifests in naïve vs. memory $\mathrm{T}$ cell compartments. In particular, Macedo et al. (2009) found that when proliferation was used as a read-out, it appeared as though there was a higher precursor frequency of alloreactive $\mathrm{T}$ cells among naïve as compared to memory CD8 ${ }^{+}$ $\mathrm{T}$ cells. However, when perforin/granzyme expression was used as a read-out, it appeared as though there was a higher precursor frequency of alloreactive $\mathrm{T}$ cells among $\mathrm{T}_{\mathrm{EM}}$ as compared to naïve $\mathrm{CD}^{+} \mathrm{T}$ cells (Macedo et al., 2009). It should therefore be noted that even though the frequencies of alloreactive $\mathrm{T}$ cell clones might be comparable between naïve and memory $\mathrm{T}$ cell compartments, the immunological manifestation of recognition of alloantigen might be very different, with potential profound impacts on graft acceptance vs. rejection.

\section{HOW ARE ALLOREACTIVE MEMORY T CELLS GENERATED?}

The generation of donor-reactive memory $T$ cells can arise through multiple independent mechanisms (Figure 1), and it is likely that many if not all of the these mechanisms are at play within the memory $\mathrm{T}$ cell compartment of a given individual. The generation of donor-reactive memory $\mathrm{T}$ cells can be subdivided into three main categories: (1) generation of "traditional" donor-reactive memory $\mathrm{T}$ cells following sensitization with alloantigen, (2) the generation of memory through antigen-independent mechanisms, and (3) the generation of allo-cross-reactive memory T cells following exposure to non-alloantigens. First, donor-reactive memory $\mathrm{T}$ cells can certainly arise from prior sensitization with allogeneic tissue. Reports from both experimental models (Valujskikh et al., 2002; Zhai et al., 2002) and clinical patients (Heeger et al., 1999) revealed worse outcomes in recipients of a prior graft, consistent with "second set" rejection (Figure 1). Alloreactive memory $\mathrm{T}$ cells can also arise during pregnancy, during which time the female can be primed against paternal antigens carried by the fetus (van Halteren et al., 2009). Furthermore, a recent study also found that immunity generated following platelet transfusion was sufficient to induce rejection following a subsequent bone marrow transplantation in murine recipients, even across only minor histocompatibility antigens (Patel et al., 2009). Since platelet transfusion is a common occurrence prior to liver transplantation in particular, these data indicate that the subpopulation of highly tranfused transplant recipients may be at an increased risk for memory T cell-mediated graft rejection.

Second, alloreactive memory $\mathrm{T}$ cells may be generated in an antigen-independent manner when in a lymphopenic environment exists in the host. In these instances, naïve $\mathrm{CD} 4^{+}$and $\mathrm{CD} 8^{+}$ alloreactive precursors are induced to undergo IL-7-dependent homeostatic proliferation and differentiation into memory $\mathrm{T}$ cells (Goldrath et al., 2000; Murali-Krishna and Ahmed, 2000; Figure 1). Seminal studies from Turka and colleagues showed that both adoptive transfer of lymphocytes into $\mathrm{T}$ and B-cell devoid SCID recipients and experimental depletion of lymphocytes in murine transplant recipients resulted in rapid reconstitution of 
A

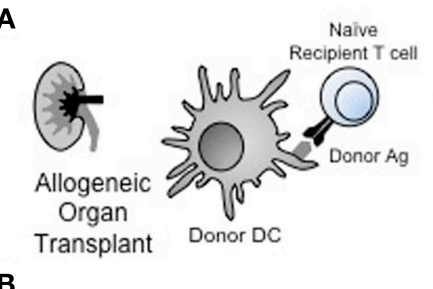

B

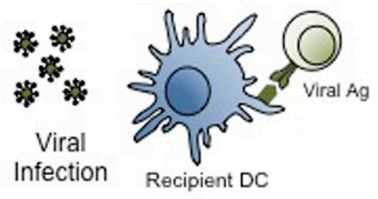

C

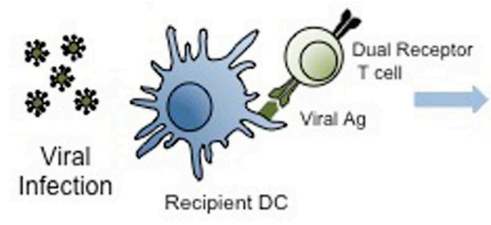

D

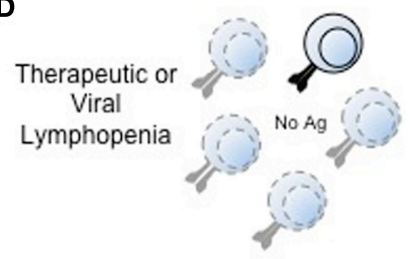

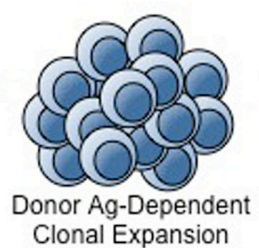

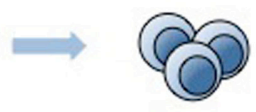

Donor Ag-Specific Memory T Cells

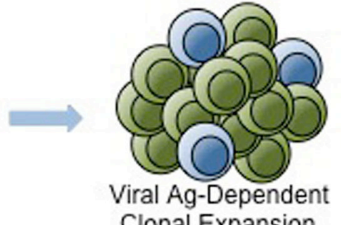

Clonal Expansion

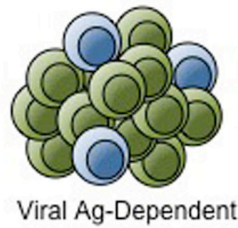

Clonal Expansion

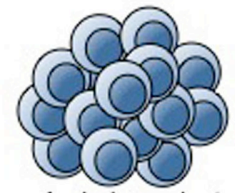

Ag-Independent Homeostatic Expansion

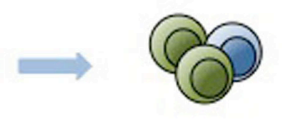

Donor Ag Cross-Reactive Viral Memory T Cells

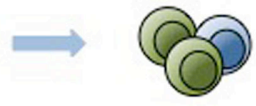

Donor Ag-Specific Memory $\mathrm{T}$ cells

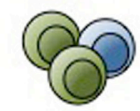

Donor Ag CrossReactive Memory $\mathrm{T}$ Cells
FIGURE 1 | Generation of donor-reactive memory T cells. An alloreactive memory $T$ cell pool may be generated through at least four different pathways. (A) Traditional donor-reactive memory may form following sensitization with alloantigen presented by donor or recipient antigen-presenting cells. (B) Pathogen-derived antigen, such as viral antigens, may elicit $\mathrm{T}$ cell memory that is cross-reactive with alloantigen. (C) Dual-receptor T cells may be activated by non-allogeneic antigen, creating memory populations that are alloreactive through the second T cell receptor. (D) Lymphopenia induced by pharmacological treatment or infection may induce antigen-independent homeostatic proliferation and generate alloreactive memory $T$ cells. Light blue and green $T$ cells represent naïve T cells. Clonally expanding T cell populations contain combinations of pathogen-reactive (green) and alloreactive (blue) cells. Memory populations also contain pathogen-reactive and alloreactive T cells. Ag, antigen. DC, dendritic cell. peripheral T cell compartments with memory $\mathrm{T}$ cells (Wu et al., 2004). These findings may be clinically relevant in that lymphopenia can be induced in patients following infection with a viral pathogen such as HIV, or following therapeutic depletion of $\mathrm{T}$ cells for the treatment of autoimmunity or transplantation, and residual naïve $\mathrm{T}$ cells might be induced to undergo rapid division and acquisition of a memory-like phenotype (Sener et al., 2009). Studies from non-transplant models have revealed that these "pseudomemory" $T$ cells have functional characteristics similar to those of memory T cells as well (Goldrath et al., 2000; Murali-Krishna and Ahmed, 2000). Thus, lymphopenia-induced immunologic memory seems to be both as phenotypically and functionally competent as true antigen-dependent memory. Memory cells generated in this manner have also been shown to constitute a barrier to tolerance induction, discussed more below ( $\mathrm{Wu}$ et al., 2004).

A third and often-overlooked mechanism by which donorreactive memory $\mathrm{T}$ cells might be generated is through the activation of dual-receptor T cells (Figure 1). Although most T cells express a single alpha and beta chain by virtue of the principle of allelic exclusion of $\mathrm{T}$ cell receptor (TCR) genes, the existence of $\mathrm{T}$ cells expressing either two alpha or two beta chains has been documented. Indeed, Lanzavecchia's laboratory showed that up to $30 \%$ of human $\mathrm{T}$ cells express a second alpha chain at the mRNA level and $8 \%$ expressed one at the protein level (Padovan et al., 1993). Thus, one could envision a situation in which two distinct TCRs, one specific for an alloantigen and one specific for a pathogen, could co-exist on the same $\mathrm{T}$ cell. If that $\mathrm{T}$ cell encounters the pathogen-derived antigen for which it is specific, it could become activated and differentiate into a memory $\mathrm{T}$ cell. If that same $\mathrm{T}$ cell were at some future time to encounter its cognate alloantigen, it would respond as memory $\mathrm{T}$ cell despite never have seen that antigen before. What is the evidence that dual-receptor alloreactive T cells exist and can participate in graft rejection? A recent study by Allen's group showed that dual-receptor $\mathrm{CD} 4^{+}$ $\mathrm{T}$ cells were enriched in the alloreactive $\mathrm{T}$ cell compartment in a murine model of graft-versus-host disease (Morris and Allen, 2009). However, the contribution of dual-receptor T cells to rejection of solid organs and in human patients warrants further investigation. 


\section{TCR CROSS-REACTIVITY AND THE GENERATION OF ALLOREACTIVE MEMORY}

In addition to the mechanisms discussed above, studies in both mouse and human have revealed that alloreactive memory $\mathrm{T}$ cells can in fact be generated by prior exposure to pathogens (Pantenburg et al., 2002; Adams et al., 2003; Brehm et al., 2003). This can occur through a process termed heterologous immunity (Pantenburg et al., 2002; Adams et al., 2003; Brehm et al., 2003), whereby TCRs present on virus-specific memory T cells cross-react with alloantigen (Figure 1). This phenomenon is based upon the intrinsic cross-reactivity of most TCRs to a wide spectrum of related peptide:MHC ligands, defined in early seminal studies wherein amino acid substitutions at TCR contact residues within the original antigenic ligand revealed that individual TCRs responded to a spectrum of peptides with unrelated or minimally related sequences, and that stimulation with these peptides could evoke differential quantity and quality of responses from the T cell (Evavold et al., 1993; Sloan-Lancaster and Allen, 1996; Ford and Evavold, 2004). Interestingly, it has been estimated that a single TCR may be capable of recognizing up to $10^{6}$ distinct ligands, and computational analysis of the $\mathrm{T}$ cell repertoire suggested that this high degree of TCR cross-reactivity is in fact required for complete coverage of the multitude of potential peptide epitopes that could be generated by pathogens (Nikolich-Zugich et al., 2004). The implications of this intrinsic cross-reactivity support the concept of heterologous immunity, suggesting that microbial pathogens might activate antigen-specific $T$ cells that then cross-react with allogeneic tissue and result in graft rejection. Experimental evidence that such cross-reactivity between pathogen-derived and graft-derived epitopes includes seminal studies by Burrows et al. (1994, 1995, 1997) demonstrating that $\mathrm{CD}^{+} \mathrm{T}$ cells specific for EBV-EBNA3A restricted by HLA-B8 were cross-reactive with HLA-B44 presenting a self-peptide with a sequence unrelated to the EBNA3A epitope. This self-peptide displays a restricted pattern of expression, a finding which has important implications for the tissue-specificity of alloimmunity (D'Orsogna et al., 2011a). Other examples of documented cross-reactivity between viral and alloepitopes include evidence that $\mathrm{CD} 4^{+} \mathrm{T}$ cells-specific for a tetanus toxoid peptide presented in the context of HLA-DR3 were cross-reactive with HLA-DR4 (Umetsu et al., 1985), and a T cell specific for HSV-VP13/14 in the context of A2 has been shown to cross-react with HLA-B44 (Koelle et al., 2002). While early studies documented the existence of cross-reactivity in these settings, they failed to rule out bystander activation as a potential explanation for the observed results. More recently, however, new experimental evidence has emerged identifying true molecular mimicry as a potential explanation for the observed alloreactivity within heterologous immune responses. Most prominently, in a recent seminal study interrogating the specificity of alloreactive $\mathrm{CD}^{+}{ }^{+} \mathrm{T}$ cells for peptide:MHC complexes, Felix et al. found that alloreactive $\mathrm{T}$ cells have the inherent propensity to respond to multiple, distinct peptide epitopes that did not share sequence homology (Felix et al., 2007). The same finding was also observed in $\mathrm{CD}^{+}$human $\mathrm{T}$ cell clones, in that when syngeneic human $\mathrm{T}$ cell populations were primed with a specific tumor antigen, the responding $\mathrm{T}$ cell clones were highly specific for the immunizing antigen, as would be expected (Falkenburg et al., 2011). However, in surprising contrast, when allogeneic $\mathrm{T}$ cell populations were primed with the same tumor antigen, the responding $\mathrm{CD}^{+} \mathrm{T}$ cell clones were specific for not only the immunizing antigen, but a wide range of both related and unrelated peptide epitopes (Falkenburg et al., 2011). Taken together, these data demonstrated that alloreactive $\mathrm{T}$ cells are more "poly-specific" as compared to conventional $\mathrm{T}$ cells and thus may possess the ability to recognize many unrelated peptide sequences (Felix and Allen, 2007). The concept of the "poly-specificity" of alloreactive T cells was further confirmed by the results of McCluskey et al. who interrogated the molecular mechanisms underlying the observed cross-reactivity of EBV-EBNA3A/HLA-B08 restricted TCR with HLA-B44 molecules (Macdonald et al., 2009). Using a crystal structure-based approach, their findings suggested that the binding modes of a single TCR to two distinct, unrelated cognate and allogeneic peptide:MHC complexes were virtually identical. Interestingly, these data also supported an induced-fit model of TCR recognition of alloepitopes, since it was only following TCR ligation that the viral and allopeptides acquired the same conformation (Beddoe et al., 2009; Macdonald et al., 2009). Taken together, these recent advances have therefore definitively demonstrated that heterologous immunity between pathogen-derived and transplant antigens can function at the level of molecular mimicry, facilitated in part by the intrinsic promiscuity of alloreactive $\mathrm{T}$ cell clones.

While these examples confirmed the existence of molecular mimicry as a mechanism underlying heterologous immunity, until very recently the experimental evidence for the existence of virally elicited allo-cross-reactive memory $\mathrm{T}$ cells was based on examples of specific donor-recipient pairs eliciting cross-reactivity between pathogen-elicited memory $\mathrm{T}$ cells and alloepitopes, but lacked a systematic evaluation of the prevalence of this phenomenon. A study by Amir et al. (2010) suggested that heterologous immunity is not limited to a few anecdotal instances, but in fact is quite common. Using MHC tetramers for FACS-purify pathogenspecific $\mathrm{T}$ cell lines and clones, the authors tested the reactivity of these cells against a panel of HLA-typed target cells. Strikingly, they observed that fully $80 \%$ of CD ${ }^{+}$T cell lines and $45 \%$ of pathogen-specific $\mathrm{CD}^{+} \mathrm{T}$ cell clones exhibited alloreactivity against at least one MHC allele (Amir et al., 2010). Subsequent experiments utilizing a TCR gene transfer approach confirmed that both the pathogen- and alloreactivity could be conferred by a single TCR, thus demonstrating true TCR cross-reactivity and ruling out the involvement of dual-receptor T cells in these instances (Amir et al., 2010). The potential for pathogen-induced alloreactive $\mathrm{T}$ cell responses to manifest clinically were highlighted in a recent case report study in which a de novo alloreactive $\mathrm{T}$ cell response was generated following varicella-zoster vaccination in an individual awaiting renal transplantation (D'Orsogna et al., $2011 b)$. In sum, these recent studies demonstrating that pathogenelicited allo-cross-reactive $\mathrm{T}$ cell memory is perhaps much more common than originally anticipated may have important implications for the field of transplantation (D'Orsogna et al., 2010). Specifically, if a large proportion of memory $\mathrm{T}$ cell clones possess intrinsic alloreactivity, and a given patient possesses tens of millions of memory $\mathrm{T}$ cell clones, the relevant question is not simply if donor-reactive memory $\mathrm{T}$ cells exist in any given individual, but 
rather the extent to which they exist, and to assess whether their frequency, phenotype, and functionality results in a significant barrier to tolerance or even long-term graft survival.

\section{ALLOREACTIVE T CELL MEMORY IS HIGHLY DONOR-SPECIFIC}

Despite intrinsic cross-reactive potential of TCRs, studies of virusspecific human memory $\mathrm{T}$ cell clones revealed that while allocross-reactivity was indeed very common, this cross-reactivity was usually confined to a single HLA molecule (Amir et al., 2010). Thus, while several studies have now shown that that alloreactivity exists among memory, the extent to which donor-reactive memory $\mathrm{T}$ cells are present appears to be highly dependent on the donor tissue tested. This is an important finding because it had previously been hypothesized that due to the lower activation threshold of memory $\mathrm{T}$ cells, many different alloantigens might be capable of stimulating memory T cells. In a 2007 study, Benichou and coworkers stimulated $\mathrm{CD}^{+}$memory $\mathrm{T}$ cells from 11 different non-human primates with a panel of 14 different stimulator cells, and found that the donor-reactive $\mathrm{CD} 8^{+}$memory $\mathrm{T}$ cell precursor frequencies within a given individual spanned an over 40 -fold range depending on the allostimulator used (Nadazdin et al., 2010). Interestingly, the authors also reported that naive alloreactive $\mathrm{T}$ cell precursor frequencies did not range as widely across the different responder: stimulator pairs tested, suggesting that the observed difference in donor-reactive memory $\mathrm{T}$ cell precursor frequencies was not due to intrinsic differences in the alloreactive $\mathrm{T}$ cell repertoires of these animals, but instead was likely due to differences in their immunologic histories (Nadazdin et al., 2010).

\section{BYSTANDER ACTIVATION: PATHOGEN-SPECIFIC RESPONSES THAT INFLUENCE ALLOREACTIVITY IN AN ANTIGEN-INDEPENDENT MANNER}

The above studies definitively demonstrate that TCR crossreactivity is an important mechanism by which pathogen infection can result in alloimmunity and therefore pose a barrier to long-term graft survival. However, it is critical to note that nonspecific so-called bystander activation also plays an important role in the pathogen-mediated barrier to allograft acceptance. Indeed, studies in murine models of infection prior to and/or following transplantation have demonstrated that both the type of infection and timing relative to transplantation can influence the impact of infections on alloimmunity. In particular, previous reports have shown that simultaneous infection of a murine transplant recipient with LCMV Armstrong or with Listeria monocytogenes can increase alloreactivity, accelerating rejection and potentially abrogating tolerance induction (Williams et al., 2001; Wang et al., 2008). However, similar studies showed that infection with LCMV Armstrong after tolerance was already established did not impact graft survival (Williams et al., 2001), and infection with LCMV Armstrong prior to transplantation abrogated tolerance induction in only $7 \%$ of mice (Williams et al., 2002). In contrast, prior infection of transplant recipients with LCMV clone 13, which persists for the life of the host, completely inhibited tolerance induction in $100 \%$ of the recipients (Williams et al., 2002). Furthermore, established tolerance in murine models can be broken by subsequent infection with Listeria but not Staphylococcus aureus (Wang et al., 2010). Overall, these findings indicate that the inflammatory milieu of a particular viral or bacterial infection can impact the priming and/or recall of alloimmune responses (Ahmed et al., 2011a). The mechanisms underlying this phenomenon involve the ability of a particular infectious agent to induce the adjuvant effects of IL-6 and type I interferons (Wang et al., 2010; Ahmed et al., 2011b), and also likely the ability of pathogen infections to license dendritic cells that may also be presenting alloepitopes (Alegre et al., 2008a,b), either through the direct or indirect pathway.

The tropism of the viral pathogen is also likely to play a role in determining its impact on alloreactive $\mathrm{T}$ cell responses and ultimately on tolerance induction. For example, if the virus infects the transplanted organ, as in the case of hepatitis $\mathrm{C}$ virus or $\mathrm{BK}$ virus, viral-specific $\mathrm{T}$ cells may play a greater role in mediating bystander activation of alloreactive $\mathrm{T}$ cells and thus inhibiting tolerance induction. This phenomenon was demonstrated experimentally following infection of murine renal allograft recipients with mouse polyoma virus, a relative of human $\mathrm{BK}$ virus that infects the kidney, revealing that polyoma virus infection resulted in acute rejection of allogeneic but not syngeneic transplanted kidneys (Han Lee et al., 2006). The authors also demonstrated a concomitant increase in alloantigen-specific $\mathrm{CD} 8^{+} \mathrm{T}$ cells by flow cytometry (Han Lee et al., 2006). Subsequent studies have failed to detect TCR cross-reactivity of viral-specific T cells with alloepitopes, suggesting instead that the increased inflammatory milieu generated by the viral infection in the kidney increased the activation and differentiation of the alloreactive $\mathrm{T}$ cell clones in an antigen-independent manner.

\section{MEMORY T CELLS POSE A BARRIER TO TOLERANCE INDUCTION}

As discussed above, memory $\mathrm{T}$ cells are distinct from their naïve counterparts with regards to both phenotype and function, possessing both a lower activation threshold and ability to respond rapidly upon restimulation (Lanzavecchia and Sallusto, 2000a,b). Memory T cells are also hallmarked by their reduced requirement for both TCR stimulation (signal one) and costimulatory signals (signal two) for recall responses (Lanzavecchia and Sallusto, 2000b; London et al., 2000). In addition, memory cells express higher levels of adhesion molecules such as LFA-1, VLA-4, and CD44, cytokine receptors such as CD122 and IL-15R $\alpha$, and anti-apoptotic molecules of the Bcl-2 family relative to naïve T cells (Zhang et al., 1998; Grayson et al., 2000, 2001). They also possess altered levels of transcription factors T-bet, eomesodermin, and Blimp-1 as compared to naïve or effector T cells. Due in large part to these changes, donor-reactive memory $\mathrm{T}$ cells are therefore relatively refractory to several distinct therapeutic interventions with unrelated mechanisms of action. First, results from analysis of human samples reveals that memory $\mathrm{T}$ cells are more resistant to even conventional immunosuppression, as transplant recipients bearing a higher frequency of pre-transplant IFN- $\gamma$-producing memory $\mathrm{T}$ cells exhibited poorer graft outcomes following treatment with a standard calcineurin inhibitor-based regimen (Heeger et al., 1999). Furthermore, perhaps the most well-studied of example of the memory $\mathrm{T}$ cell barrier is the observed resistance of donor-specific 
memory $\mathrm{T}$ cells, elicited either by exposure to donor antigens or viral pathogens, to tolerance induction via CD40 and CD28 costimulation blockers (Pantenburg et al., 2002; Valujskikh et al., 2002; Zhai et al., 2002; Adams et al., 2003). In contrast, numerous studies have demonstrated that blockade of these costimulatory pathways during transplantation are highly effective in tolerizing naïve donor-reactive $\mathrm{T}$ cells and lead to prolonged graft survival in both murine and non-human primate models (Linsley et al., 1992; Larsen et al., 1996; Kirk et al., 1997). Importantly, the costimulatory requirements of donor-reactive memory $\mathrm{T}$ cells during transplantation are particularly relevant in that reagents designed to block CD28 costimulatory molecules were recently FDA approved for the prevention of graft rejection (Vincenti et al., 2005, 2010; Durrbach et al., 2010). This observed costimulation independence of donor-reactive memory $\mathrm{T}$ cells in models of transplantation may have been predicted from basic in vitro analyses of $\mathrm{T}$ cell function demonstrating that memory $\mathrm{T}$ cells could become fully activated following in vitro stimulation with B7-deficient APC (Croft et al., 1994; Bachmann et al., 1999; Kim et al., 1999; London et al., 2000), and the finding that CD28-1mice do not exhibit a gross impairment in their ability to generate memory $\mathrm{T}$ cells in response to LCMV infection, or for these memory $\mathrm{T}$ cells to respond upon secondary rechallenge (Suresh et al., 2001). In transplant models, a seminal study examining the pathogen-elicited memory barrier revealed that while CD28 and CD154 costimulation blockade effectively inhibited graft rejection in naïve recipients, animals that had previously been infected with one, two, or three different viruses were relatively refractory to the tolerance-inducing effects of costimulation blockade (Adams et al., 2003). While this study focused primarily on the $\mathrm{CD}^{+}$memory $\mathrm{T}$ cell barrier, it is clear that both $\mathrm{CD} 4^{+}$and $\mathrm{CD} 8{ }^{+}$ donor-specific memory cells can constitute a barrier to costimulation blockade-induced tolerance (Adams et al., 2003; Chen et al., 2004). For example, similar studies showed that mice infected with Leishmania major exhibited increased resistance to costimulation blockade-induced acceptance of fully MHC disparate allografts, and attributed this resistance to allo-cross-reactive $\mathrm{CD} 4^{+} \mathrm{T}$ cells primed by Leishmania infection (Pantenburg et al., 2002). In addition, approaches that utilized total body irradiation or nonmyeloablative conditioning in combination with costimulatory blockade to induce mixed hematopoietic chimerism in recipient animals were highly efficacious at inducing tolerance in naïve laboratory mice (Sykes and Sachs, 1988; Sykes et al., 1997; Durham et al., 2000; Adams et al., 2001; Sykes, 2001), but met with less uniform success in the translation of this strategy to non-human primates (Kawai et al., 1995, 1999a,b, 2001a,b, 2004; Kean et al., 2007), which, among other challenges, have much higher frequencies of memory $\mathrm{T}$ cells in their peripheral blood than laboratory mice housed in specific pathogen free conditions (Kean et al., 2006; Ochiai et al., 2007). Importantly, a recent study examining the efficacy of combined costimulatory blockade/bone marrow or donor-specific transfusion (DST)-based based approach to induce tolerance in non-human primate recipients of renal transplants showed that higher pre-transplant precursor frequencies of donor-reactive memory $\mathrm{T}$ cells (as measured by ELISPOT) correlated with failure of tolerance induction and acute rejection of the grafts, while low pre-transplant donor-reactive memory $\mathrm{T}$ cell frequencies portended successful tolerance induction and longterm renal allograft survival (Ford and Larsen, 2011; Nadazdin et al., 2011). In support of these findings, a similar study used the same costimulatory blockade/DST based strategy to attempt to induce tolerance to a previously transplanted kidney (Koyama et al., 2007). Their results showed that this regimen, while successful at inducing tolerance when the DST and renal allograft were transplanted simultaneously, failed in the case where the donor was essentially pre-sensitized due to prior transplantation of the renal allograft. The authors of this study showed that memory $\mathrm{T}$ cells were refractory to the tolerance induction regimen and therefore were likely responsible for the failure of the establishment of tolerance in these recipients (Koyama et al., 2007).

In addition to their resistance to costimulation blockade and chimerism based therapies, memory $\mathrm{T}$ cells demonstrate a relative resistance to antibody-mediated depletion using both antilymphocyte serum (ALS) in mice (Minamimura et al., 2008) or alemtuzumab (Campath-1H) in humans (Pearl et al., 2005). These memory $\mathrm{T}$ cells that can persist following treatment with depletional therapy are also poised to undergo homeostatic expansion and repopulate the host during reconstitution (Pearl et al., 2005). The mechanisms underlying the relative resistance of memory $\mathrm{T}$ cells to antibody-mediated depletion are not well understood. The increased expression of anti-apoptotic molecules such as Bcl-2 family members may be responsible for the observed increased resistance to death, however, an alternative hypothesis is that monoclonal antibodies or other therapeutics present at high concentrations in the bloodstream may not necessarily achieve these high concentrations in peripheral tissues, which are sites to which effector memory T cells home (Woodland and Kohlmeier, 2009). Understanding the ability of monoclonal antibodies to target tissue resident memory $\mathrm{T}$ cells remains an important area of future investigation.

Lastly, memory T cells have also been shown to exhibit increased resistance to regulation by $\mathrm{CD} 4{ }^{+} \mathrm{CD} 25^{+}$FoxP3 regulatory $\mathrm{T}$ cells $\left(\mathrm{T}_{\text {reg }}\right)$. This observation was first made in a murine adoptive transfer model, wherein transferred $\mathrm{CD} 4{ }^{+} \mathrm{CD} 25^{+}$cells effectively inhibited the rejection mediated by naïve but not memory CD4 ${ }^{+}$ T cells (Yang et al., 2007). Regulatory T cells were similarly found unable to regulate $\mathrm{CD}^{+}$alloreactive $\mathrm{T}$ cell responses. Interestingly, this was true for both naïve $\mathrm{T}_{\text {reg }}$ and alloantigen "primed" $\mathrm{T}_{\text {reg, }}$, suggesting that strategies to enhance the frequency and/or activation of alloantigen-specific FoxP $3^{+} \mathrm{T}_{\text {reg }}$ are unlikely to be effective against donor-reactive memory $\mathrm{T}$ cells ( $\mathrm{Li}$ and Turka, 2010). A subsequent study revealed a similar resistance of human alloreactive memory $\mathrm{T}$ cells to regulation by traditional $\mathrm{CD} 4^{+}$ $\mathrm{CD}^{2} 5^{+}$FoxP3 $^{+} \mathrm{T}_{\text {reg }}$ (Afzali et al., 2011). However, a more recent report suggested that in vitro stimulation of human $\mathrm{T}$ cells with TLR-stimulated plasmacytoid dendritic cells resulted in the generation of $\mathrm{CD}^{+}{ }^{+} \mathrm{FoxP}^{+}{ }^{+} \mathrm{LAG}-3^{+} \mathrm{CTLA}-4^{+}$regulatory $\mathrm{T}$ cells that were effective at inhibiting alloreactive memory $\mathrm{T}$ cell responses (Boor et al., 2011).

\section{HETEROGENEITY WITHIN THE MEMORY T CELL COMPARTMENT}

The last 20 years have witnessed major advances in our understanding of the generation, maintenance, and function of $\mathrm{T}$ cell 
memory. This work has led to the understanding that memory $\mathrm{T}$ cells are do not constitute a homogenous population but rather exhibit a wide array of phenotypes, functional properties, and trafficking patterns that render them likely to play discrete roles in protective immune responses. Memory CD4 ${ }^{+}$and $\mathrm{CD}^{+} \mathrm{T}$ cells are often segregated into two subsets, central $\left(\mathrm{T}_{\mathrm{CM}}\right)$ and effector ( $\left.\mathrm{T}_{\mathrm{EM}}\right)$ memory (Sallusto et al., 1999), which even still is likely a gross oversimplification of the range of diversity contained within the memory $\mathrm{T}$ cell compartment. $\mathrm{T}_{\mathrm{CM}}$ express the lymph node homing receptors CD62L and CCR7, whereas $\mathrm{T}_{\mathrm{EM}}$ lack these markers and instead express other adhesion molecules and chemokine receptors which allow them to access peripheral tissues (Wherry et al., 2003; Sallusto et al., 2004). In addition, $\mathrm{T}_{\mathrm{CM}}$ and $\mathrm{T}_{\mathrm{EM}}$ differ in terms of their capacity for re-expansion upon recall, in that $\mathrm{T}_{\mathrm{CM}}$ have high proliferative potential, express CD27, elaborate IL-2 upon following re-encounter with antigen (Wherry et al., 2003). Conversely, $\mathrm{T}_{\mathrm{EM}}$ possess lower proliferative potential and reside primarily in non-lymphoid tissues, making them poorly suited to mount secondary re-expansion of antigenspecific T cell populations (Wherry et al., 2003). However, these memory $\mathrm{T}$ cells likely constitute a first line of defense, in that they are immediately cytolytic upon Ag re-exposure, and rapidly secrete inflammatory cytokines such as IFN- $\gamma$ and TNF (Hislop et al., 2001; Wherry et al., 2003; Bouneaud et al., 2005; Marzo et al., 2005; Roberts et al., 2005). Specifically, recent work from Fairchild's laboratory demonstrated that memory $\mathrm{T}$ cells have the potential to infiltrate allografts within $12-24 \mathrm{~h}$, and showed that this very early infiltration was antigen-independent (Schenk et al., 2008). It is likely that the route of exposure, dose, replication rate, and tropism of the infectious challenge all play important roles in determining the relative proportion of each memory $\mathrm{T}$ cell subset persisting after infection, and also the degree to which each subset participates in protective immunity upon rechallenge (Masopust et al., 2006). For example, Oberbarnscheidt et al. (2008) showed in a study that $\mathrm{CD} 8^{+} \mathrm{T}_{\mathrm{CM}}$ and $\mathrm{T}_{\mathrm{EM}}$ rejected allografts with equivalent kinetics in wild-type hosts. However, in animals lacking secondary lymphoid organs, $\mathrm{CD} 8^{+} \mathrm{T}_{\mathrm{EM}}$ were significantly better than $\mathrm{T}_{\mathrm{CM}}$ at inducing rejection (Oberbarnscheidt et al., 2008). With regard to heterogeneity in effector function, previous work in models of pathogen-specific immunity and vaccination demonstrated that multi-cytokine producing memory cells exhibited superior protective function following secondary challenge with antigen (Seder et al., 2008). A 2009 study from Kirk and colleagues revealed that this is likely also true for alloreactive memory $\mathrm{T}$ cells, in that $\mathrm{CD} 2{ }^{\text {hi }}$ multi-cytokine producing $\mathrm{T}_{\mathrm{EM}}$ were associated with break-through rejection responses in a non-human primate model of renal transplantation (Weaver et al., 2009). In addition, these $\mathrm{CD} 2^{\text {hi }}$ multi-cytokine producing $\mathrm{T}_{\mathrm{EM}}$ expressed the cytolytic effector molecule granzymeB and underwent degranulation in vitro (Weaver et al., 2009). Similar findings were also true in studies of human alloreactive memory $\mathrm{T}$ cell responses (Lo et al., 2011). Thus, this increased effectiveness in mediating graft rejection may be linked to the ability to carry out a wide range of effector functions, each of which has the potential to contribute to graft destruction. Taken together, these data highlight the distinct roles of individual memory $\mathrm{T}$ cell subsets in mediating allograft rejection.

\section{COSTIMULATION-INDEPENDENT RECALL RESPONSES: NOT}

\section{ALL MEMORY IS CREATED EQUALLY}

This new understanding that memory $\mathrm{T}$ cells actually encompasses a wide spectrum of cellular phenotypes, functionalities, and trafficking patterns, suggests that despite the current dogma that memory T cells do not require CD28/B7 and/or CD154/CD40 signals for recall responses, memory $\mathrm{T}$ cells may in fact exhibit a range of requirements for costimulation during recall. In particular, the finding that blockade of CD28 can ameliorate established autoimmunity in murine models of multiple sclerosis and type 1 diabetes suggest that memory $\mathrm{T}$ cells existing in these models could be inhibited following blockade of the CD28 pathway (Khoury et al., 1995). Furthermore, administration of abatacept (CTLA-4 Ig) to human patients results in the amelioration of both psoriasis and rheumatoid arthritis, both diseases mediated by memory $\mathrm{T}$ cells against self antigens (Abrams et al., 1999; Kremer et al., 2003; Bluestone et al., 2006). Importantly, a recent study by Katsikis et al. found that $\mathrm{CD}^{+}$memory $\mathrm{T}$ cells derived from adoptively transferred cells required CD28mediated costimulation for optimal recall responses in a model of bacterial infection (Borowski et al., 2007). Taken together, these findings suggest that under certain circumstances, memory $\mathrm{T}$ cells may depend on CD28 and/or CD154 mediated costimulation in order to generate optimum secondary recall responses.

The concept that memory $\mathrm{T}$ cells are not uniform in their costimulation blockade resistance has been demonstrated in transplant models as well. First, several studies have demonstrated that $\mathrm{CD}^{+}$memory cells as a whole exhibit increased susceptibility to CD28/CD154 costimulation blockade during recall as compared with $\mathrm{CD}^{+}$memory T cells (Adams et al., 2003; Ndejembi et al., 2006). In addition, there is evidence from adoptive transfer experiments in fully allogeneic experimental models that $\mathrm{T}_{\mathrm{CM}}$ elicited via prior sensitization with $\mathrm{BALB} / \mathrm{c}$ antigen posed a greater barrier to costimulation blockade-induced tolerance as compared with $\mathrm{T}_{\mathrm{EM}}$ (Adams et al., 2003). However, in a model of allo-specific heterologous immunity following latent viral infection with a murine $\mathrm{EBV}$ homolog, $\mathrm{T}_{\mathrm{EM}}$ as opposed to $\mathrm{T}_{\mathrm{CM}}$ were the culprits in terms of forming a barrier to tolerance induction (Stapler et al., 2008). In studies of human transplant recipients, $\mathrm{T}_{\mathrm{EM}}$ (and not as much $\mathrm{T}_{\mathrm{CM}}$ ) have been implicated as posing a relative barrier to the effects of therapeutic lymphocyte depletion via either anti-thymocyte globulin or Campath-H1 (Pearl et al., 2005).

In a recent study, we sought to determine the priming conditions that influenced the programming of costimulationindependent donor-reactive memory T cells. Previous work in models of viral infection revealed that the amount/duration of antigen exposure profoundly impacted the programmed differentiation of memory $\mathrm{T}$ cells into short-lived effectors vs. longlived memory precursors, and influenced the phenotype and functionality of the resulting memory $\mathrm{T}$ cell population (Sarkar et al., 1975; Blair and Lefrancois, 2007; Kalia et al., 2008). We interrogated the effect of differential duration of antigen exposure during the initial priming phase of the response on the programming of costimulation-independent donor-reactive memory T cells during recall (Floyd et al., 2011). This series 
of experiments made use of a system in which OVA-specific TCR transgenic $\mathrm{T}$ cells were primed by OVA-expressing Listeria, resulting in the generation of pathogen-elicited donorreactive memory $\mathrm{T}$ cells. In order to limit the duration of antigen exposure of donor-reactive cells during priming, recipients were treated with ampicillin post-infection. These recipients were subsequently transplanted with an OVA-expressing skin graft to induce a secondary recall response in the presence or absence of CD28 and CD154/CD40 costimulation blockade. Results of these studies revealed that skin graft recipients bearing donor-reactive memory $\mathrm{T}$ cell responses which had been elicited under conditions of reduced antigen exposure exhibited similar frequencies and phenotypes of antigen-specific $\mathrm{T}$ cells as compared with non-ampicillin-treated controls (Floyd et al., 2011). However, these donor-reactive $\mathrm{T}$ cells were unable to mediate costimulation blockade-resistant rejection of the OVA-expressing skin graft, indicating that the amount/duration of antigen exposure is a critical factor in determining memory $\mathrm{T}$ cells' relative requirement for CD28/CD154 costimulation in the generation of a functional recall response following transplantation.

\section{MOUNTAIN OR MOLEHILL? POTENTIAL STRATEGIES TO OVERCOME THE MEMORY BARRIER}

Pre-existing donor-reactive memory $\mathrm{T}$ cells are likely to be a foe of long-term allograft survival no matter which immunosuppressive strategy is employed (Figure 2). For instance, studies assessing the pre-transplant frequency of donor-reactive memory $\mathrm{T}$ cells have identified a direct correlation between donor-reactive memory $\mathrm{T}$ cell precursor frequency (measured by IFN- $\gamma$ production following short ex vivo restimulation) and increased risk of acute rejection while on standard calcineurin inhibitor-based immunosuppression (Heeger et al., 1999). However, direct assessment of the impact of calcineurin inhibition on alloreactive memory $\mathrm{T}$ cell responses revealed a strong inhibition of alloreactive $\mathrm{T}$ cell proliferation (Pearl et al., 2005). While calcineurin inhibition may effectively attenuate memory $\mathrm{T}$ cell recall responses, it is also associated with a number of off-target toxicities that lead to the development of hyperlipidemia, type II diabetes, cardiovascular events, and, not insignificantly, renal failure (Halloran, 2004). Identification and therapeutic targeting of those pathways critical for the initiation and maintenance of donor-reactive memory $\mathrm{T}$ cells is an important area of investigation in the field. As discussed above, work in

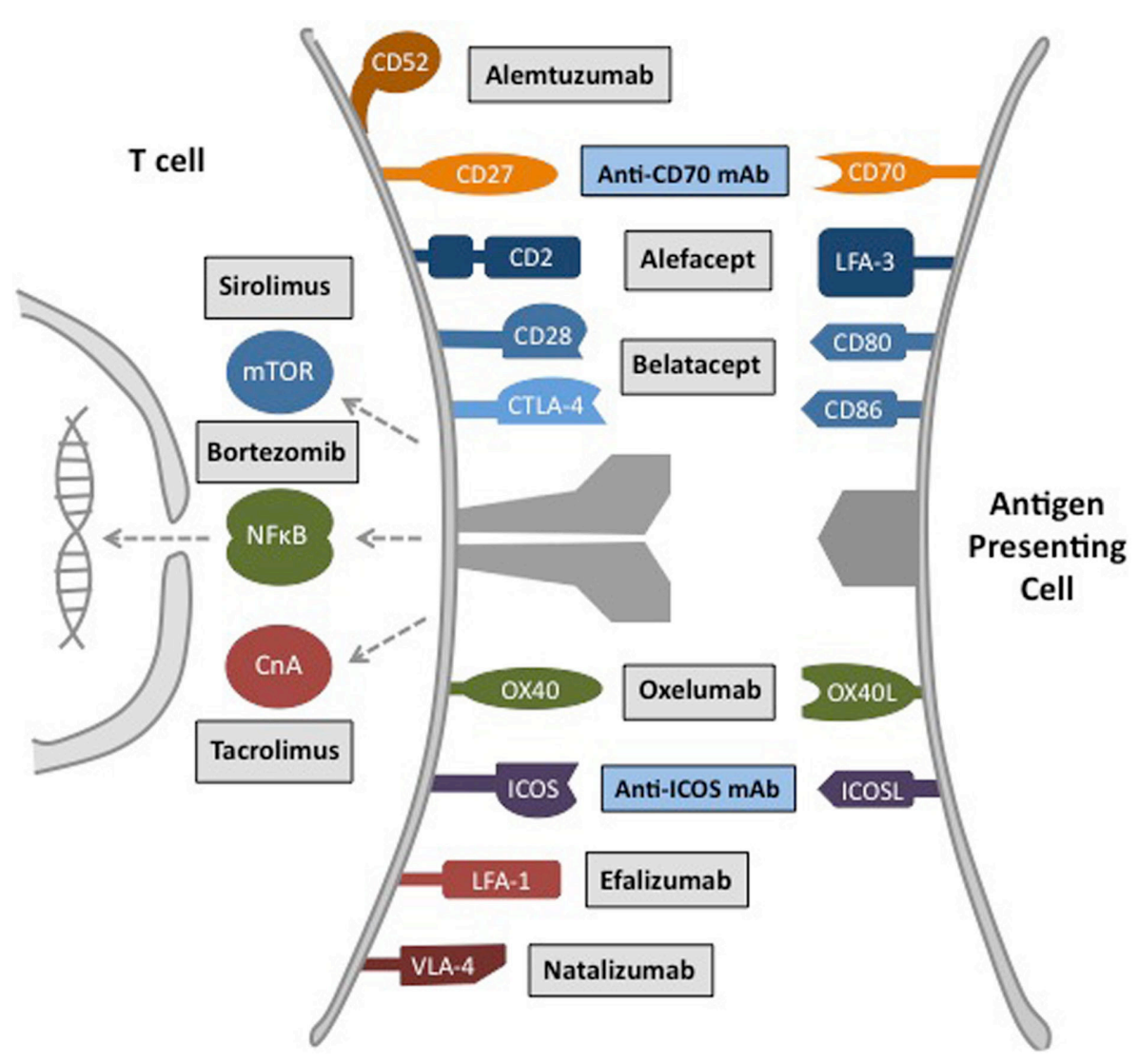

FIGURE 2 | Major therapeutic targets for inhibition of donor-reactive memory $\mathbf{T}$ cell responses. Transplantation therapeutics have been developed that target memory $T$ cell costimulation pathways, intracellular signaling pathways, and trafficking molecules. Alemtuzumab, anti-CD52 monoclonal antibody. Alefacept, LFA-3 Ig fusion protein. Belatacept, high-affinity CTLA-4 Ig fusion protein. Anti-OX40L mAb, anti-OX40 ligand monoclonal antibody.
Efalizumab, anti-LFA-1 monoclonal antibody. Natalizumab, anti-VLA-4 monoclonal antibody. Sirolimus, Mammalian Target of Rapamycin (mTOR) pathway inhibitor. Tacrolimus, Calcineurin A (CnA)-NFAT pathway inhibitor. Oxelumab, anti-OX40 monoclonal antibody. Bortezomib, protease inhibitor. Gray box, FDA approved therapeutic. Blue box, experimental therapeutic under clinical development. 
animal models has revealed that memory $\mathrm{T}$ cells are for the most part not effectively inhibited by CD28 costimulation blockade. This increased resistance may in part explain the increased incidence and severity of acute rejection episodes observed in patients treated with the CD28 blocker belatacept (Larsen et al., 2005), as compared to cyclosporine-treated controls in recent Phase II and Phase II studies of renal transplant recipients (Vincenti et al., 2005, 2010; Durrbach et al., 2010). Determining whether high pre-transplant donor-reactive memory $\mathrm{T}$ cell precursor frequency actually correlates with increased incidence and severity of acute rejection in human renal allograft recipients treated with belatacept constitutes an important area of future research. Thus, as use of belatacept in clinical transplantation is likely to increase following its FDA approval in June 2011, the need to simultaneously attenuate donor-reactive memory $\mathrm{T}$ cell responses by targeting memory cell-specific pathways becomes more pressing.

As such, several groups have studied the mechanisms by which memory $\mathrm{T}$ cells escape tolerance induction following costimulatory blockade. $\mathrm{Vu}$ et al. (2006) reported that targeting OX40, but not inducible costimulatory molecule (ICOS), CD70, or $41 \mathrm{BB}$ could synergize with CD28/CD40 blockade to inhibit rejection mediated by donor-reactive memory cells, but in most experiments rejection ultimately ensued. In contrast, others have observed that anti-CD70 could inhibit rejection mediated by memory cells in mice lacking lymph nodes (Yamada et al., 2005). Given their homing properties, it seems likely rejection in this model may be mediated primarily by $\mathrm{T}_{\mathrm{EM}}$, although the relative abundance of donor-reactive cells in the various memory subsets was not defined. In addition, Valujskikh and colleagues recently interrogated the role of ICOS (CD278) in the ability of early graft-infiltrating memory $\mathrm{T}$ cells to initiate effector functions associated with graft rejection (Schenk et al., 2009). Their results revealed that while ICOS was not constitutively expressed on all memory T cells, its expression was upregulated in situ following proliferation of memory $\mathrm{T}$ cells within the graft itself. Importantly, blockade of ICOS signaling on memory $\mathrm{T}$ cells led to a significant decrease in the early expression of IFN- $\gamma$, perforin, granzyme B, and FasL mRNA within memory T cell-infiltrated allograft (Schenk et al., 2009). In other settings, CD4 ${ }^{+}$memory cells escaped anti-CD154 therapy and could provide help for $\mathrm{CD}^{+} \mathrm{T}$ cell responses, macrophage activation, and anti-donor antibody production (Chen et al., 2004), and it is tempting to speculate that the $\mathrm{T}_{\mathrm{FH}}$ memory subset that expresses TRANCE and CD30L may have contributed to this CD154 independent rejection (Crotty, 2011). Furthermore, previous work has shown that the $\mathrm{NF} \kappa \mathrm{B}$ inhibitor deoxyspergualin synergized with CD28/CD40 blockade (Adams et al., 2003) to inhibit graft rejection predominantly mediated by $\mathrm{CD}^{+} \mathrm{T}_{\mathrm{CM}}$. More recent studies have confirmed these early findings by demonstrating that reagents which block proteasome degradation and thereby inhibit NFкB nuclear translocation also showed efficacy as inhibitors of donorreactive memory $\mathrm{T}$ cell responses. Specifically, a recent in vitro study demonstrated the ability of bortezomib, one such proteasome inhibitor, to effectively inhibit activation of memory $\mathrm{T}$ cells in vitro (Kim et al., 2009). As an added benefit, bortezomib also preserved regulatory $\mathrm{T}$ cell function in these studies (Kim et al., 2009).
It is well established that memory $\mathrm{T}$ cells mediate graft rejection by rapidly trafficking into allografts and elaborating inflammatory cytokines that recruit in other innate and adaptive immune cells, activating the endothelium and epithelium of the graft, and executing their cytolytic function. Thus, one potential strategy to limit their pathogenicity might be to block the ability of memory T cells to migrate into the transplanted tissue. In 2011, Fairchild and colleagues demonstrated that the early infiltration of memory $\mathrm{T}$ cells into donor tissue was suppressed following treatment with LFA1 antagonists (Setoguchi et al., 2009; Figure 2), and our group showed that anti-LFA-1 mAb synergized with traditional costimulation blockade in effectively diminishing the donor-reactive memory T cell response in murine models (Kitchens et al., 2011a). This synergy was mediated by a decrease in donor-reactive memory $\mathrm{T}$ cell cytokine secretion and cytolytic function in the spleen and draining lymph nodes in addition to a diminution in antigenspecific T cell trafficking into the graft (Kitchens et al., 2011a). Furthermore, recent translational studies in a non-human primate model of islet transplantation revealed that a short course of anti-LFA-1 synergized with belatacept in inhibiting alloislet rejection (Badell et al., 2010). In addition, efalizumab, initially developed and FDA approved for the inhibition of autoreactive $\mathrm{T}$ cell responses during psoriasis, was recently tested in phase II clinical trials in both renal and islet transplantation (Vincenti et al., 2007; Posselt et al., 2010; Turgeon et al., 2010). These studies assessed the utility of an efalizumab-based regimen in inhibiting rejection in recipients of pancreatic islet allografts. Hundred percent of the patients treated with efalizumab in the two islet studies maintained insulin independence for the duration of treatment with the drug (Posselt et al., 2010; Turgeon et al., 2010). Unfortunately, efalizumab was voluntarily withdrawn by the manufacturer in 2009 due to detection of progressive multi-focal leukoencephalopathy (PML) in patients treated with efalizumab. This rare but potentially fatal JC polyoma-associated disease has thus occurred in only four of $\sim 46,000$ treated subjects $(0.008 \%$; Carson et al., 2009). While this is clearly a devastating complication, the PML risk associated with efalizumab is not higher than that associated with cyclosporine $(0.045 \%)$, tacrolimus $(0.021 \%)$, or mycophenolate mofetil (0.035\%; Neff et al., 2008). Overall, the large number of treated psoriatic patients combined with relatively rare incidence of side effects suggests that blockade of the LFA-1 pathway may warrant further investigation for the prophylaxis of transplant rejection (Kitchens et al., 2011b), in order to circumvent the nephrotoxicity and other side effects associated with current calcineurin inhibitor-based immunosuppressive regimens.

Other adhesion molecule pathways that have been targeted in order to overcome the memory T cell barrier include VLA-4, and adhesion molecule that is not expressed by naïve $\mathrm{T}$ cells and that is upregulated upon activation (Theien et al., 2001).VLA-4 is critical for T cell entry into peripheral tissues (Kuchroo et al., 1993) and has blockade of this pathway has been FDA approved for use in multiple sclerosis (natalizumab; Figure 2). We recently showed in a murine model of experimental transplantation that treatment with anti-VLA-4 monoclonal antibodies synergized with costimulatory blockade in inhibiting allograft rejection mediated by donor-reactive memory T cells (Kitchens et al., 2011a). While antiVLA-4 failed to impact donor-reactive memory $\mathrm{T}$ cell expansion, 
cytokine secretion, or cytolytic function, it potently inhibited the ability of donor-reactive memory $\mathrm{T}$ cells to traffic into allografts (Kitchens et al., 2011a). Furthermore, Kirk and colleagues recently reported the ability of $\mathrm{CD} 2^{\text {hi }} \mathrm{T}_{\mathrm{EM}}$ cells to mediate $\mathrm{CD} 28$ costimulation blockade-resistant rejection, and subsequently targeted these cells using the CD2 adhesion molecule blocker LFA-3-Ig (alefacept; Weaver et al., 2009; Figure 2). When administered as part of a regimen consisting also of CTLA-4 Ig (CD28 blockade) and sirolimus (mTOR inhibition), CD2 adhesion molecule blockade resulted in renal allograft survival beyond the duration of treatment (>90 days) in five out of eight non-human primate renal allograft recipients (Weaver et al., 2009). These results provided the experimental foundation for the translation of alefacept, which is currently FDA approved for use in plaque psoriasis, as an adjunct therapy to be used in combination with CD28 blockers such as belatacept to inhibit donor-reactive memory $\mathrm{T}$ cell responses in transplantation.

As discussed above, studies have shown that donor-reactive memory $\mathrm{T}$ cells are resistant to the effects of regulation (Yang et al., 2007). However, recently published data have shown that the ability of memory $\mathrm{T}$ cells to mediate the early recruitment of neutrophils into transplanted allografts underlies their resistance to regulation (Jones et al., 2010). Indeed, depletion of neutrophils from murine transplant recipients resulted in the ability of adoptively transferred $\mathrm{T}_{\text {reg }}$ to suppress the activity of donor-reactive memory $\mathrm{T}$ cells, resulting in long-term graft survival (Jones et al., 2010). These results indicate that the ability of memory $\mathrm{T}$ cells to activate the innate immune system following transplantation is an important mechanism by which they facilitate graft rejection, and suggest that therapeutic manipulation of these innate immune components could be utilized in overcoming the memory barrier.

\section{MAINTAINING MEMORY: PROTECTIVE IMMUNITY IN TRANSPLANTATION}

The overall goal of immunomodulatory therapy following transplantation is to inhibit graft rejection while maintaining protective immunity. While transplant recipients on current immunosuppressive regimens can certainly experience infectious complications, the fact that patients are not immediately overcome with opportunistic infections indicates that some degree of protective immunity is intact, very likely due to the inability of these immunosuppressive regimens to inhibit immunologic memory. Thus, strategies designed to inhibit alloreactive memory $\mathrm{T}$ cells must be weighed against the cost of potentially attenuating protective immunity. For example, as mentioned above, use of LFA-1 and VLA-4 antagonists in autoimmunity (psoriasis and multiple sclerosis, respectively), have resulted in the development of PML, in a small but significant subset of patients (Carson et al., 2009). Thus, elucidating ways to increase protective immunity while at the same time inhibit alloreactive $\mathrm{T}$ cell responses is critical to increasing patient health and decreasing morbidity following transplantation.

Given its history as an immunosuppressive and antiproliferative agent, surprising observations were made when investigators began to interrogate the impact of rapamycin monotherapy on antigen-specific T cell responses during the course of viral or bacterial infection. In two studies published in Nature in 2009,
Araki et al. (2009) and Pearce et al. (2009) demonstrated a paradoxical immunostimulatory effect of rapamycin on the CD8 ${ }^{+}$ memory $\mathrm{T}$ cell response following pathogen infection. Administration of a clinically relevant dose (serum levels of 5-25 ng/ml) of rapamycin during the priming phase was found to actually increase the number of virus-specific memory T cells. Furthermore, when rapamycin was administered during the contraction phase of the response alone, the antigen-specific $\mathrm{T}$ cells instead increased in quality, acquiring a more $\mathrm{T}_{\mathrm{CM}}$-like phenotype (CD62L ${ }^{\text {hi }} \mathrm{KLRG}-1^{\text {lo }}$ $\left.\mathrm{CD} 27^{\mathrm{hi}} \mathrm{Bcl}-2^{\mathrm{hi}}\right)$ with increased proliferative capacity upon rechallenge. In a series of elegant RNAi knock-down experiments, the authors went on to show that this enhancement in virus-specific responses is a $\mathrm{T}$ cell-intrinsic effect (Araki et al., 2009). Thus, in addition to potential other described effects of mTOR inhibition on dendritic cells, $\mathrm{T}_{\text {reg }}$, or other immune compartments (Thomson et al., 2009), these studies point to a direct effect of rapamycin on $\mathrm{CD}^{+} \mathrm{T}$ cells to enhance both the quantity and quality of memory $\mathrm{T}$ cell differentiation in response to pathogen exposure in vivo.

These surprising findings raised the question of whether clinically relevant dosing of rapamycin monotherapy following transplantation would also augment graft-specific $\mathrm{CD}^{+} \mathrm{T}$ cell responses. Was the enhancing effect of rapamycin being masked by the presence of other immunosuppressants following transplantation? Or was there a fundamental difference in the effect of rapamycin on $\mathrm{T}$ cells responding to antigen in the context of a graft versus a pathogen? To address these questions, our group compared the responses of identical monoclonal TCR transgenic T cells to the same epitope presented by either a graft or a pathogen, in the presence of rapamycin, and found that while rapamycin augmented the OVA-specific CD ${ }^{+} \mathrm{T}$ cell response in the context of a bacterial infection, it failed to augment the OVA-specific response in the setting of a transplant (Ferrer et al., 2010). Additional studies revealed that rapamycin also inhibited $\mathrm{CD}^{+} \mathrm{T}$ cell responses to a heterotopic heart transplant or a DST, but augmented CD8 ${ }^{+}$ $\mathrm{T}$ cell responses to the transplant-relevant pathogens murine $\gamma$ herpes virus (an EBV homolog) and murine polyoma virus (a BK/JC homolog). Furthermore, concurrent infection with Listeria did not restore the enhancing effect of rapamycin on the graft-specific T cells, suggesting that pathogen-associated inflammatory signals provided in trans were not sufficient to replicate the rapamycin-induced augmentation (Ferrer et al., 2010). Since the TCR affinity, antigen recognized, and dose and timing of rapamycin administration was identical in both groups, these data suggested a fundamental difference in the way rapamycin impacts $\mathrm{T}$ cells stimulated in the context of a pathogen vs. the context of a graft. Understanding the mechanisms underlying this dichotomous effect of rapamycin on graft- vs. pathogen-specific $\mathrm{T}$ cell responses might facilitate the inhibition of alloreactive $\mathrm{T}$ cell responses while simultaneously preserving protective immunity.

\section{SUMMARY}

Memory $\mathrm{T}$ cells represent a yin and yang for transplant recipients, as these cells are intimately involved and in most cases absolutely required for the maintenance of protective immunity in the face of some degree of immunosuppression, yet from the evidence presented here they clearly constitute a formidable 
barrier for the successful implementation of tolerance induction strategies in transplantation. However, based on recent observations that the precursor frequency of alloreactive memory $\mathrm{T}$ cells is highly donor-specific, determination of quantity (and likely quality) of donor-specific $\mathrm{T}$ cell memory for a particular donor/recipient combination would allow stratification of relative

\section{REFERENCES}

Abrams, J. R., Lebwohl, M. G., Guzzo, C. A., Jegasothy, B. V., Goldfarb, M. T., Goffe, B. S., Menter, A., Lowe, N. J., Krueger, G., Brown, M. J., Weiner, R. S., Birkhofer, M. J., Warner, G. L., Berry, K. K., Linsley, P. S., Krueger, J. G., Ochs, H. D., Kelley, S. L., and Kang, S. (1999). CTLA4Ig-mediated blockade of Tcell costimulation in patients with psoriasis vulgaris. J. Clin. Invest. 103, 1243-1252.

Adams, A. B., Durham, M. M., Kean, L., Shirasugi, N., Ha, J., Williams, M. A., Rees, P. A., Cheung, M. C., Mittelstaedt, S., Bingaman, A. W., Archer, D. R., Pearson, T. C., Waller, E. K., and Larsen, C. P. (2001). Costimulation blockade, busulfan, and bone marrow promote titratable macrochimerism, induce transplantation tolerance, and correct genetic hemoglobinopathies with minimal myelosuppression. J. Immunol. 167, 1103-1111.

Adams, A. B., Williams, M. A., Jones, T. R., Shirasugi, N., Durham, M. M., Kaech, S. M., Wherry, E. J., Onami, T., Lanier, J. G., Kokko, K. E., Pearson, T. C., Ahmed, R., and Larsen, C. P. (2003). Heterologous immunity provides a potent barrier to transplantation tolerance. J. Clin. Invest. 111, 1887-1895.

Afzali, B., Mitchell, P. J., Scotta, C., Canavan, J., Edozie, F. C., Fazekasova, H., Lord, G. M., John, S., Barber, L. D., Hernandez-Fuentes, M. P., Lechler, R. I., and Lombardi, G. (2011). Relative resistance of human CD4(+) memory T cells to suppression by $\mathrm{CD} 4(+) \mathrm{CD} 25(+)$ regulatory T cells. Am. J. Transplant. 11, 1734-1742.

Ahmed, E. B., Daniels, M., Alegre, M. L., and Chong, A. S. (2011a). Bacterial infections, alloimmunity, and transplantation tolerance. Transplant. Rev. (Orlando). 25, 27-35.

Ahmed, E. B., Wang, T., Daniels, M., Alegre, M. L., and Chong, A. S. (2011b). IL-6 induced by Staphylococcus aureus infection prevents the induction of skin allograft acceptance in mice. Am. J. Transplant. 11, 936-946.

Ahmed, R., and Gray, D. (1996). Immunological memory and protective immunity: understanding their relation. Science 272, 54-60.

Alegre, M. L., Goldstein, D. R., and Chong, A. S. (2008a). Toll-like receptor signaling in transplantation. Curr. Opin. Organ Transplant 13, 358-365.

Alegre, M. L., Leemans, J., Le Moine, A. Florquin, S., De Wilde, V., Chong, A., and Goldman, M. (2008b). The multiple facets of toll-like receptors in transplantation biology. Transplantation 86, 1-9.

Amir, A. L., D’Orsogna, L. J., Roelen, D. L., van Loenen, M. M., Hagedoorn, R. S., de Boer, R., van der Hoorn, M. A., Kester, M. G., Doxiadis, II, Falkenburg, J. H., Claas, F. H., and Heemskerk, M. H. (2010). Allo-HLA reactivity of virus-specific memory T-cells is common. Blood 115, 3146-3157.

Araki, K., Turner, A. P., Shaffer, V. O., Gangappa, S., Keller, S. A., Bachmann, M. F., Larsen, C. P., and Ahmed, R. (2009). mTOR regulates memory CD8 T-cell differentiation. Nature 460, 108-112.

Araki, Y., Fann, M., Wersto, R., and Weng, N. P. (2008). Histone acetylation facilitates rapid and robust memory CD8 $\mathrm{T}$ cell response through differential expression of effector molecules (eomesodermin and its targets: perforin and granzyme B). J. Immunol. 180, 8102-8108.

Bachmann, M. F., Gallimore, A., Linkert, S., Cerundolo, V., Lanzavecchia, A., Kopf, M., and Viola, A. (1999). Developmental regulation of Lck targeting to the CD8 coreceptor controls signaling in naive and memory T cells. J. Exp. Med. 189, 1521-1530.

Badell, I. R., Russell, M. C., Thompson, P. W., Turner, A. P., Weaver, T. A., Robertson, J. M., Avila, J. G., Cano, J. A., Johnson, B. E., Song, M., Leopardi, F. V., Swygert, S., Strobert, E. A., Ford, M. L., Kirk, A. D., and Larsen, C. P. (2010). LFA-1-specific therapy prolongs allograft survival in rhesus macaques. J. Clin. Invest. 120, 4520-4531.

Banerjee, A., Gordon, S. M., Intlekofer, A. M., Paley, M. A., Mooney, E. C., Lindsten, T., Wherry, E. J., and Reiner, S. L. (2010). Cutting edge: the transcription factor eomesodermin

risk of alloreactive memory $\mathrm{T}$ cell mediated rejection, or conversely, likelihood of successful establishment of tolerance. This strategy would allow for circumvention of the memory barrier in certain patients, while ongoing research is aimed at designing new strategies to overcome it without critically impairing protective immunity.

enables CD8 + T cells to compete for the memory cell niche. J. Immunol. 185, 4988-4992.

Beddoe, T., Chen, Z., Clements, C. S. Ely, L. K., Bushell, S. R., Vivian, J. P., Kjer-Nielsen, L., Pang, S. S., Dunstone, M. A., Liu, Y. C., Macdonald, W. A., Perugini, M. A., Wilce, M. C. Burrows, S. R., Purcell, A. W., Tiganis, T., Bottomley, S. P., McCluskey, J., and Rossjohn, J. (2009). Antigen ligation triggers a conformational change within the constant domain of the alphabeta $\mathrm{T}$ cell receptor. Immunity 30, 777-788.

Blair, D. A., and Lefrancois, L. (2007) Increased competition for antigen during priming negatively impacts the generation of memory CD4 T cells. Proc. Natl. Acad. Sci. U.S.A. 104 15045-15050.

Bluestone, J. A., St Clair, E. W., and Turka, L. A. (2006). CTLA4Ig: bridging the basic immunology with clinical application. Immunity 24 233-238.

Boor, P. P., Metselaar, H. J., Jonge, S., Mancham, S., van der Laan, L. J. and Kwekkeboom, J. (2011). Human plasmacytoid dendritic cells induce CD8 LAG-3 Foxp3 CTLA-4 regulatory $\mathrm{T}$ cells that suppress alloreactive memory $\mathrm{T}$ cells. Eur. J. Immunol. 41, 1663-1674.

Borowski, A. B., Boesteanu, A. C., Mueller, Y. M., Carafides, C., Topham, D. J., Altman, J. D., Jennings, S. R., and Katsikis, P. D. (2007). Memory CD8+ T cells require $\mathrm{CD} 28$ costimulation. $J$ Immunol. 179, 6494-6503.

Bouneaud, C., Garcia, Z., Kourilsky, P., and Pannetier, C. (2005). Lineage relationships, homeostasis, and recall capacities of central- and effector-memory CD8 T cells in vivo. J. Exp. Med. 201, 579-590.

Brehm, M. A., Markees, T. G., Daniels, K. A., Greiner, D. L., Rossini, A. A., and Welsh, R. M. (2003). Direct visualization of cross-reactive effector and memory allo-specific CD8 T cells generated in response to viral infections. J. Immunol. 170, 4077-4086.

Burrows, S. R., Khanna, R., Burrows, J. M., and Moss, D. J. (1994). An alloresponse in humans is dominated by cytotoxic $\mathrm{T}$ lymphocytes (CTL) cross-reactive with a single EpsteinBarr virus CTL epitope: implications for graft-versus-host disease. J. Exp. Med. 179, 1155-1161.

Burrows, S. R., Silins, S. L., Khanna, R., Burrows, J. M., Rischmueller, M., McCluskey, J., and Moss, D. J. (1997). Cross-reactive memory $\mathrm{T}$ cells for Epstein-Barr virus augment the alloresponse to common human leukocyte antigens: degenerate recognition of major histocompatibility complex-bound peptide by $\mathrm{T}$ cells and its role in alloreactivity. Eur. J. Immunol. 27, 1726-1736.

Burrows, S. R., Silins, S. L., Moss, D. J., Khanna, R., Misko, I. S., and Argaet, V. P. (1995). T cell receptor repertoire for a viral epitope in humans is diversified by tolerance to a background major histocompatibility complex antigen. J. Exp. Med. 182, 1703-1715.

Carson, K. R., Focosi, D., Major, E. O., Petrini, M., Richey, E. A., West, D. P., and Bennett, C. L. (2009). Monoclonal antibody-associated progressive multifocal leucoencephalopathy in patients treated with rituximab, natalizumab, and efalizumab: a review from the research on adverse drug events and reports (RADAR) project. Lancet Oncol. 10, 816-824.

Chen, Y., Heeger, P. S., and Valujskikh, A. (2004). In vivo helper functions of alloreactive memory CD4+ $\mathrm{T}$ cells remain intact despite donorspecific transfusion and anti-CD40 ligand therapy. J. Immunol. 172, 5456-5466.

Chevalier, N., Jarrossay, D., Ho, E., Avery, D. T., Ma, C. S., Yu, D., Sallusto, F., Tangye, S. G., and Mackay, C. R. (2011). CXCR5 expressing human central memory CD4 T cells and their relevance for humoral immune responses. J. Immunol. 186, 5556-5568.

Croft, M., Bradley, L. M., and Swain, S. L. (1994). Naive versus memory CD4 $\mathrm{T}$ cell response to antigen. Memory cells are less dependent on accessory cell costimulation and can respond to many antigen-presenting cell types including resting B cells. Immunol. J. 152, 2675-2685.

Crotty, S. (2011). Follicular helper CD4 T cells (TFH). Annu. Rev. Immunol. 29, 621-663. 
D’Orsogna, L. J., Roelen, D. L., Doxiadis, II, and Claas, F. H. (2010). Alloreactivity from human viral specific memory T-cells. Transpl. Immunol. 23, 149-155.

D’Orsogna, L. J., Roelen, D. L., van der Meer-Prins, E. M., van der Pol, P., Franke-van Dijk, M. E., Eikmans, M., Anholts, J., Rossjohn, J., McCluskey, J., Mulder, A., van Kooten, C., Doxiadis, II, and Claas, F. H. (2011a). Tissue specificity of cross-reactive allogeneic responses by EBV EBNA3Aspecific memory T cells. Transplantation 91, 494-500.

D’Orsogna, L. J., van Besouw, N. M., van der Meer-Prins, E. M., van der Pol, P., Franke-van Dijk, M., Zoet, Y. M., van der Slik, A., Weimar, W., van Kooten, C., Mulder, A., Roelen, D. L., Doxiadis, II, and Claas, F. H. (2011b). Vaccine-induced alloHLA-reactive memory $\mathrm{T}$ cells in a kidney transplantation candidate. Transplantation 91, 645-651.

Durham, M. M., Bingaman, A. W., Adams, A. B., Ha, J., Waitze, S. Y., Pearson, T. C., and Larsen, C. P. (2000). Cutting edge: administration of anti-CD40 ligand and donor bone marrow leads to hemopoietic chimerism and donor-specific tolerance without cytoreductive conditioning. J. Immunol. 165, 1-4.

Durrbach, A., Pestana, J. M., Pearson, T., Vincenti, F., Garcia, V. D., Campistol, J., Rial, M. C., Florman, S., Block, A., Russo, G. D., Xing, J., Garg, P., and Grinyó, J. (2010). A phase III study of belatacept versus cyclosporine in kidney transplants from extended criteria donors (BENEFIT-EXT study). Am. J. Transplant. 10, 547-557.

Evavold, B. D., Sloan-Lancaster, J., and Allen, P. M. (1993). Tickling the TCR: selective T-cell functions stimulated by altered peptide ligands. Immunol. Today 14, 602-609.

Falkenburg, W. J., Melenhorst, J. J., van de Meent, M., Kester, M. G., Hombrink, P., Heemskerk, M. H., Hagedoorn, R. S., Gostick, E., Price, D. A., Falkenburg, J. H., Barrett, A. J., and Jedema, I. (2011). Allogeneic HLA-A $* 02$-restricted WT1-specific $\mathrm{T}$ cells from mismatched donors are highly reactive but show offtarget promiscuity. J. Immunol. 187, 2824-2833.

Felix, N. J., and Allen, P. M. (2007). Specificity of T-cell alloreactivity. Nat. Rev. Immunol. 7, 942-953.

Felix, N. J., Donermeyer, D. L., Horvath, S., Walters, J. J., Gross, M. L., Suri, A., and Allen, P. M. (2007). Alloreactive $\mathrm{T}$ cells respond specifically to multiple distinct peptide-MHC complexes. Nat. Immunol. 8, 388-397.

Ferrer, I. R., Wagener, M. E., Robertson, J. M., Turner, A. P., Araki, K., Ahmed, R., Kirk, A. D., Larsen, C. P., and Ford, M. L. (2010). Cutting edge: rapamycin augments pathogen-specific but not graftreactive CD8+ T Cell Responses. J. Immunol. 185, 2004-2008.

Floyd, T. L., Wagener, M. E., Kitchens, W. H., Robertson, J. M., Cheeseman, J. A., Stempora, L., Larsen, C. P., and Ford, M. L. (2011). Limiting the amount and duration of antigen exposure during priming increases memory $\mathrm{T}$ cell requirement for costimulation during recall. J. Immunol. 186, 2033-2041.

Ford, M. L., and Evavold, B. D. (2004). Degenerate recognition of $\mathrm{T}$ cell epitopes: impact of $\mathrm{T}$ cell receptor reserve and stability of peptide:MHC complexes. Mol. Immunol. 40, 1019-1025.

Ford, M. L., and Larsen, C. P. (2011). Transplantation tolerance: memories that haunt us. Sci. Transl. Med. $3,86 \mathrm{ps} 22$.

Goldrath, A. W., Bogatzki, L. Y., and Bevan, M. J. (2000). Naive T cells transiently acquire a memorylike phenotype during homeostasisdriven proliferation. J. Exp. Med. 192, 557-564.

Grayson, J. M., Murali-Krishna, K., Altman, J. D., and Ahmed, R. (2001). Gene expression in antigen-specific CD8+ T cells during viral infection. J. Immunol. 166, 795-799.

Grayson, J. M., Zajac, A. J., Altman, J. D., and Ahmed, R. (2000). Cutting edge: increased expression of $\mathrm{Bcl}-2$ in antigen-specific memory CD8+ T cells. J. Immunol. 164, 3950-3954.

Halloran, P. F. (2004). Immunosuppressive drugs for kidney transplantation. N. Engl. J. Med. 351, 2715-2729.

Han Lee, E. D., Kemball, C. C., Wang, J., Dong, Y., Stapler, D. C., Hamby, K. M. Jr., Gangappa, S., Newell, K. A., Pearson, T. C., Lukacher, A. E., and Larsen, C. P. (2006). A mouse model for polyomavirusassociated nephropathy of kidney transplants. Am. J. Transplant. 6, 913-922.

Hand, T. W., Morre, M., and Kaech, S. M. (2007). Expression of IL-7 receptor alpha is necessary but not sufficient for the formation of memory CD8 $\mathrm{T}$ cells during viral infection. Proc. Natl. Acad. Sci. U.S.A. 104, 11730-11735.

Harrington, L. E., Janowski, K. M., Oliver, J. R., Zajac, A. J., and Weaver, C. T. (2008). Memory CD4 T cells emerge from effector T-cell progenitors. Nature 452, 356-360.

Heeger, P. S., Greenspan, N. S., Kuhlenschmidt, S., Dejelo, C., Hricik, D. E. Schulak, J. A., and Tary-Lehmann, M. . (1999). Pretransplant frequency of donor-specific, IFNgamma-producing lymphocytes is a manifestation of immunologic memory and correlates with the risk of posttransplant rejection episodes. J. Immunol. 163, 2267-2275.

Hislop, A. D., Gudgeon, N. H., Callan, M. F., Fazou, C., Hasegawa, H. Salmon, M., and Rickinson, A B. (2001). EBV-specific CD8+ T cell memory: relationships between epitope specificity, cell phenotype, and immediate effector function. $J$. Immunol. 167, 2019-2029.

Huster, K. M., Busch, V., Schiemann, M., Linkemann, K., Kerksiek, K. M., Wagner, H., and Busch, D. H. (2004). Selective expression of IL-7 receptor on memory $\mathrm{T}$ cells identifies early CD40L-dependent generation of distinct CD8 + memory $\mathrm{T}$ cell subsets. Proc. Natl. Acad. Sci. U.S.A. 101, 5610-5615.

Intlekofer, A. M., Takemoto, N., Kao, C., Banerjee, A., Schambach, F., Northrop, J. K., Shen, H., Wherry, E. J., and Reiner, S. L. (2007). Requirement for T-bet in the aberrant differentiation of unhelped memory CD8+ T cells. J. Exp. Med. 204, 2015-2021.

Intlekofer, A. M., Takemoto, N., Wherry, E. J., Longworth, S. A., Northrup, J. T., Palanivel, V. R., Mullen, A. C., Gasink, C. R., Kaech, S. M., Miller, J. D., Gapin, L., Ryan, K., Russ, A. P., Lindsten, T., Orange, J. S., Goldrath, A. W., Ahmed, R., and Reiner, S. L. (2005). Effector and memory CD8 $+\mathrm{T}$ cell fate coupled by T-bet and eomesodermin. Nat. Immunol. 6, 1236-1244.

Jones, N. D., Brook, M. O., CarvalhoGaspar, M., Luo, S., and Wood, K. J. (2010). Regulatory $\mathrm{T}$ cells can prevent memory CD8+ T-cellmediated rejection following polymorphonuclear cell depletion. Eur. J. Immunol. 40, 3107-3116.

Joshi, N. S., Cui, W., Chandele, A., Lee, H. K., Urso, D. R., Hagman, J., Gapin, L., and Kaech, S. M. (2007). Inflammation directs memory precursor and short-lived effector CD8(+) T cell fates via the graded expression of T-bet transcription factor. Immunity 27, 281-295.

Kaech, S. M., Tan, J. T., Wherry, E. J., Konieczny, B. T., Surh, C. D., and Ahmed, R. (2003). Selective expression of the interleukin 7 receptor identifies effector CD8 T cells that give rise to long-lived memory cells. Nat. Immunol. 4, 1191-1198.

Kalia, V., Sarkar, S., and Ahmed, R. (2008). Fine-tuning CD4+ central memory $\mathrm{T}$ cell heterogeneity by strength of stimulation. Eur. J. Immunol. 38, 15-19.

Kallies, A., Xin, A., Belz, G. T., and Nutt, S. L. (2009). Blimp-1 transcription factor is required for the differentiation of effector CD8(+) $\mathrm{T}$ cells and memory responses. Immunity 31, 283-295.

Kawai, T., Abrahamian, G., Sogawa, H., Wee, S., Boskovic, S., Andrew, D., Nadazdin, O., Mauiyyedi, S., Weymouth, D., Ko, D., Colvin, R., Sachs, D., and Cosimi, A. (2001a). Costimulatory blockade for induction of mixed chimerism and renal allograft tolerance in nonhuman primates. Transplant. Proc. 33, 221-222.

Kawai, T., Sogawa, H., Abrahamian, G., Boskovic, S., Wee, S. L., Nadazdin, O., Andrews, D., Ko, D., Mauiyyedi, S., Colvin, R. B., Sachs, D. H., and Cosimi, A. B. (2001b). Long-term results of CD154 blockade for induction of mixed chimerism and kidney allograft tolerance in non-human primates. Am. J. Transplant. 1(Suppl. 1), 275.

Kawai, T., Cosimi, A. B., Colvin, R. B., Powelson, J., Eason, J., Kozlowski, T., Sykes, M., Monroy, R., Tanaka, M., and Sachs, D. H. (1995). Mixed allogeneic chimerism and renal allograft tolerance in cynomolgus monkeys. Transplantation 59, 256-262.

Kawai, T., Poncelet, A., Sachs, D. H., Mauiyyedi, S., Boskovic, S., Wee, S. L., Ko, D. S., Bartholomew, A., Kimikawa, M., Hong, H. Z., Abrahamian, G., Colvin, R. B., and Cosimi, A. B. (1999a). Long-term outcome and alloantibody production in a non-myeloablative regimen for induction of renal allograft tolerance. Transplantation 68, 1767-1775.

Kawai, T., Sachs, D. H., and Cosimi, A. B. (1999b). Tolerance to vascularized organ allografts in large-animal models. Curr. Opin. Immunol. 11, 516-520.

Kawai, T., Sogawa, H., Boskovic, S., Abrahamian, G., Smith, R. N., Wee, S. L., Andrews, D., Nadazdin, O., Koyama, I., Sykes, M., Winn, H. J., Colvin, R. B., Sachs, D. H., and Cosimi, A. B. (2004). CD154 blockade for induction of mixed chimerism and prolonged renal allograft survival in nonhuman primates. Am. J. Transplant. 4, 1391-1398.

Kean, L. S., Adams, A. B., Strobert, E., Hendrix, R., Gangappa, S., 
Jones, T. R., Shirasugi, N., Rigby, M. R., Hamby, K., Jiang, J., Bello, H., Anderson, D., Cardona, K., Durham, M. M., Pearson, T. C., and Larsen, C. P. (2007). Induction of chimerism in rhesus macaques through stem cell transplant and costimulation blockadebased immunosuppression. Am. J. Transplant. 7, 320-335.

Kean, L. S., Gangappa, S., Pearson, T. C., and Larsen, C. P. (2006). Transplant tolerance in non-human primates: progress, current challenges and unmet needs. Am. J. Transplant. 6, 884-893.

Khoury, S. J., Akalin, E., Chandraker, A., Turka, L., Linsley, P. S., Sayegh, M. H., and Hancock, W. W. (1995). CD28-B7 costimulatory blockade by CTLA4-Ig prevents actively induced experiemental autoimmune encephalomyelitis and inhibits Th1 but spares Th2 cytokines in the central nervous system. Immunol. J. 155, 4521-4524.

Kim, J. S., Lee, J. I., Shin, J. Y., Kim, S. Y., Shin, J. S., Lim, J. H., Cho, H. S., Yoon, I. H., Kim, K. H., Kim, S. J., and Park, C. G. (2009). Bortezomib can suppress activation of rapamycin-resistant memory $\mathrm{T}$ cells without affecting regulatory $\mathrm{T}$-cell viability in non-human primates. Transplantation 88, 1349-1359.

Kim, S. K., Schluns, K. S., and Lefrancois, L. (1999). Induction and visualization of mucosal memory CD8 T cells following systemic virus infection. J. Immunol. 163, 4125-4132.

Kirk, A. D., Harlan, D. M., Armstrong, N. N., Davis, T. A., Dong, Y., Gray, G. S., Hong, X., Thomas, D., Fechner, J. H., and Knechtle, S. J. (1997). CTLA4Ig and anti-CD40 ligand prevent renal allograft rejection in primates. Proc. Natl. Acad. Sci. U.S.A. 94, 8789-8794.

Kitchens, W. H., Haridas, D., Wagener, M. E., Song, M., Kirk, A. D., Larsen, C. P., and Ford, M. L. (2011a). Integrin antagonists prevent costimulatory blockade-resistant transplant rejection by $\mathrm{CD} 8+$ memory $\mathrm{T}$ cells. Am. J. Transplant. 12, 69-80.

Kitchens, W. H., Larsen, C. P., and Ford, M. L. (2011b). Integrin antagonists for transplant immunosuppression: panacea or peril? Immunotherapy 3 , 305-307.

Koelle, D. M., Chen, H. B., McClurkan, C. M., and Petersdorf, E. W. (2002). Herpes simplex virus type 2-specific CD8 cytotoxic T lymphocyte crossreactivity against prevalent HLA class I alleles. Blood 99, 3844-3847.

Koyama, I., Nadazdin, O., Boskovic, S., Ochiai, T., Smith, R. N., Sykes, M.,
Sogawa, H., Murakami, T., Strom, T. B., Colvin, R. B., Sachs, D. H., Benichou, G., Cosimi, A. B., and Kawai, T. (2007). Depletion of CD8 memory $\mathrm{T}$ cells for induction of tolerance of a previously transplanted kidney allograft. Am. J. Transplant. 7, 1055-1061.

Kremer, J. M., Westhovens, R., Leon, M., Di Giorgio, E., Alten, R., Steinfeld, S., Russell, A., Dougados, M., Emery, P., Nuamah, I. F., Williams, G. R., Becker, J. C., Hagerty, D. T., and Moreland, L. W. (2003). Treatment of rheumatoid arthritis by selective inhibition of T-cell activation with fusion protein CTLA4Ig. N. Engl. J. Med. 349, 1907-1915.

Kuchroo, V. K., Martin, C. A., Greer, J. M., Ju, S. T., Sobel, R. A., and Dorf, M. E. (1993). Cytokines and adhesion molecules contribute to the ability of myelin proteolipid protein-specific $\mathrm{T}$ cell clones to mediate experimental allergic encephalomyelitis. J. Immunol. 151, 4371-4382.

Lacombe, M. H., Hardy, M. P., Rooney, J., and Labrecque, N. (2005). IL7 receptor expression levels do not identify CD8+ memory $\mathrm{T}$ lymphocyte precursors following peptide immunization. J. Immunol. 175, 4400-4407.

Landais, E., Romagnoli, P. A., Corper, A. L., Shires, J., Altman, J. D., Wilson, I. A., Garcia, K. C., and Teyton, L. (2009). New design of MHC class II tetramers to accommodate fundamental principles of antigen presentation. J. Immunol. 183, 7949-7957.

Lanzavecchia, A., and Sallusto, F. (2000a). From synapses to immunological memory: the role of sustained T cell stimulation. Curr. Opin. Immunol. 12, 92-98.

Lanzavecchia, A., and Sallusto, F. (2000b). Dynamics of T lymphocyte responses: intermediates, effectors, and memory cells. Science 290, 92-97.

Larsen, C. P., Elwood, E. T., Alexander, D. Z., Ritchie, S. C., Hendrix, R., Tucker-Burden, C., Cho, H. R., Aruffo, A., Hollenbaugh, D., Linsley, P. S., Winn, K. J., and Pearson, T. C. (1996). Long-term acceptance of skin and cardiac allografts after blocking CD40 and CD28 pathways. Nature 381, 434-438.

Larsen, C. P., Pearson, T. C., Adams, A. B., Tso, P., Shirasugi, N., Strobertm, E., Anderson, D., Cowan, S., Price, K., Naemura, J., Emswiler, J., Greene, J., Turk, L. A., Bajorath, J., Townsend, R., Hagerty, D., Linsley, P. S., and Peach, R. J. (2005). Rational development of LEA29Y (belatacept), a high-affinity variant of CTLA4-Ig with potent immunosuppressive properties. Am. J. Transplant. 5 , 443-453.

Lechler, R., Batchelor, R., and Lombardi, G. (1991). The relationship between MHC restricted and allospecific T cell recognition. Immunol. Lett. 29, 41-50.

Li, X. C., and Turka, L. A. (2010). An update on regulatory $\mathrm{T}$ cells in transplant tolerance and rejection. Nat. Rev. Nephrol. 6, 577-583.

Linsley, P. S., Wallace, P. M., Johnson, J., Gibson, M., Greene, J. L., Ledbetter, J. A., Singh, C., and Tepper, M. A. (1992). Immunosuppression in vivo by a soluble form of the CTLA- 4 T cell activation molecule. Science 257 792-795.

Lo, D. J., Weaver, T. A., Stempora, L., Mehta, A. K., Ford, M. L., Larsen, C. P., and Kirk, A. D. (2011). Selective targeting of human alloresponsive CD8+ effector memory $\mathrm{T}$ cells based on CD2 expression. Am. J. Transplant. 11, 22-33.

Lohning, M., Hegazy, A. N., Pinschewer D. D., Busse, D., Lang, K. S., Hofer, T., Radbruch, A., Zinkernagel, R. M., and Hengartner, H. (2008). Longlived virus-reactive memory $\mathrm{T}$ cells generated from purified cytokinesecreting $\mathrm{T}$ helper type 1 and type 2 effectors. J. Exp. Med. 205, 53-61.

Lombardi, G., Sidhu, S., Daly, M., Batchelor, J. R., Makgoba, W., and Lechler, R. I. (1990). Are primary alloresponses truly primary? Int. Immunol. 2, 9-13.

London, C. A., Lodge, M. P., and Abbas, A. K. (2000). Functional responses and costimulator dependence of memory CD4+ T cells. J. Immunol. 164, 265-272.

Macdonald, W. A., Chen, Z., Gras, S., Archbold, J. K., Tynan, F. E., Clements, C. S., Bharadwaj, M., KjerNielsen, L., Saunders, P. M., Wilce, M. C., Crawford, F., Stadinsky, B. Jackson, D., Brooks, A. G., Purcell, A. W., Kappler, J. W., Burrows, S. R., Rossjohn, J., and McCluskey, J. (2009). T cell allorecognition via molecular mimicry. Immunity 31, 897-908.

Macedo, C., Orkis, E. A., Popescu, I., Elinoff, B. D., Zeevi, A., Shapiro, R., Lakkis, F. G., and Metes, D. (2009). Contribution of naive and memory T-cell populations to the human alloimmune response. Am. J. Transplant. 9, 2057-2066.

Marshall, H. D., Chandele, A., Jung, Y. W., Meng, H., Poholek, A. C., Parish, I. A., Rutishauser, R., Cui, W., Kleinstein, S. H., Craft, J., and Kaech, S. M. (2011). Differential expression of
Ly6C and T-bet distinguish effector and memory Th1 CD4(+) cell properties during viral infection. Immunity 35, 633-646.

Marzo, A. L., Klonowski, K. D., Le Bon, A., Borrow, P., Tough, D. F., and Lefrancois, L. (2005). Initial T cell frequency dictates memory CD8+ $\mathrm{T}$ cell lineage commitment. Nat. Immunol. 6, 793-799.

Masopust, D., Ha, S. J., Vezys, V., and Ahmed, R. (2006). Stimulation history dictates memory CD8 $\mathrm{T}$ cell phenotype: implications for primeboost vaccination. J. Immunol. 177 , 831-839.

Masopust, D., Vezys, V., Marzo, A. L., and Lefrancois, L. (2001). Preferential localization of effector memory cells in nonlymphoid tissue. Science 291, 2413-2417.

Minamimura, K., Sato, K., Yagita, H. Tanaka, T., Arii, S., and Maki, T. (2008). Strategies to induce marked prolongation of secondary skin allograft survival in alloantigen-primed mice. Am. J. Transplant. 8, 761-772.

Morris, G. P., and Allen, P. M. (2009). Cutting edge: highly alloreactive dual TCR T cells play a dominant role in graft-versus-host disease. $J$. Immunol. 182, 6639-6643.

Murali-Krishna, K., and Ahmed, R (2000). Cutting edge: naive $\mathrm{T}$ cells masquerading as memory cells. $J$. Immunol. 165, 1733-1737.

Nadazdin, O., Boskovic, S., Murakami, T., O'Connor, D. H., Wiseman, R. W., Karl, J. A., Tuscher, J. J., Sachs, D. H., Madsen, J. C., Tocco, G. Kawai, T., Cosimi, A. B., and Benichou, G. (2010). Phenotype, distribution and alloreactive properties of memory $\mathrm{T}$ cells from cynomolgus monkeys. Am. J. Transplant. 10, 1375-1384.

Nadazdin, O., Boskovic, S., Murakami, T., Tocco, G., Smith, R. N., Colvin, R. B., Sachs, D. H., Allan, J., Madsen, J. C., Kawai, T., Cosimi, A. B., and Benichou, G. (2011). Host alloreactive memory $\mathrm{T}$ cells influence tolerance to kidney allografts in nonhuman primates. Sci. Transl. Med. 3, 86ra51.

Ndejembi, M. P., Teijaro, J. R., Patke, D. S., Bingaman, A. W., Chandok, M. R., Azimzadeh, A., Nadler, S. G., and Farber, D. L. (2006). Control of memory $\mathrm{CD} 4 \mathrm{~T}$ cell recall by the CD28/B7 costimulatory pathway. J. Immunol. 177, 7698-7706.

Neff, R. T., Hurst, F. P., Falta, E. M., Bohen, E. M., Lentine, K. L., Dharnidharka, V. R., Agodoa, L. Y., Jindal, R. M., Yuan, C. M., and Abbott, K. C. (2008). Progressive multifocal leukoencephalopathy and use of mycophenolate mofetil after 
kidney transplantation. Transplantation 86, 1474-1478.

Nikolich-Zugich, J., Slifka, M. K., and Messaoudi, I. (2004). The many important facets of T-cell repertoire diversity. Nat. Rev. Immunol. 4 , 123-132.

Oberbarnscheidt, M. H., Ng, Y. H., and Chalasani, G. (2008). The roles of CD8 central and effector memory T-cell subsets in allograft rejection. Am. J. Transplant. 8, 1809-1818.

Ochiai, T., Benichou, G., Cosimi, A. B., and Kawai, T. (2007). Induction of allograft tolerance in nonhuman primates and humans. Front. Biosci. 12, 4248-4253.

Padovan, E., Casorati, G., Dellabona, P., Meyer, S., Brockhaus, M., and Lanzavecchia, A. (1993). Expression of two $\mathrm{T}$ cell receptor alpha chains: dual receptor T cells. Science 262, 422-424.

Pantenburg, B., Heinzel, F., Das, L., Heeger, P. S., and Valujskikh, A. (2002). T cells primed by Leishmania major infection cross-react with alloantigens and alter the course of allograft rejection. J. Immunol. 169, 3686-3693.

Patel, S. R., Cadwell, C. M., Medford, A., and Zimring, J. C. (2009). Transfusion of minor histocompatibility antigen-mismatched platelets induces rejection of bone marrow transplants in mice. J. Clin. Invest. 119, 2787-2794.

Pearce, E. L., Walsh, M. C., Cejas, P. J., Harms, G. M., Shen, H., Wang, L. S., Jones, R. G., and Choi, Y. (2009). Enhancing CD8 T-cell memory by modulating fatty acid metabolism. Nature 460, 103-107.

Pearl, J. P., Parris, J., Hale, D. A., Hoffmann, S. C., Bernstein, W. B., McCoy, K. L., Swanson, S. J., Mannon, R. B., Roederer, M., and Kirk, A. D. (2005). Immunocompetent T-cells with a memory-like phenotype are the dominant cell type following antibody-mediated T-cell depletion. Am. J. Transplant. 5, 465-474.

Pepper, M., Linehan, J. L., Pagan, A. J., Zell, T., Dileepan, T., Cleary, P. P., and Jenkins, M. K. (2010). Different routes of bacterial infection induce long-lived TH1 memory cells and short-lived TH17 cells. Nat. Immunol. 11, 83-89.

Pepper, M., Pagan, A. J., Igyarto, B. Z., Taylor, J. J., and Jenkins, M. K. (2011). Opposing signals from the Bcl6 transcription factor and the interleukin-2 receptor generate Thelper 1 central and effector memory cells. Immunity 35, 583-595.

Posselt, A. M., Bellin, M. D., Tavakol, M., Szot, G. L., Frassetto, L. A.,
Masharani, U., Kerlan, R. K., Fong, L., Vincenti, F. G., Hering, B. J., Bluestone, J. A., and Stock, P. G. (2010). Islet transplantation in type 1 diabetics using an immunosuppressive protocol based on the antiLFA-1 antibody efalizumab. Am. J. Transplant. 10, 1870-1880.

Rao, R. R., Li, Q., Odunsi, K., and Shrikant, P. A. (2010). The mTOR kinase determines effector versus memory CD $8+\mathrm{T}$ cell fate by regulating the expression of transcription factors T-bet and eomesodermin. Immunity 32, 67-78.

Roberts, A. D., Ely, K. H., and Woodland, D. L. (2005). Differential contributions of central and effector memory $\mathrm{T}$ cells to recall responses. J. Exp. Med. 202, 123-133.

Rutishauser, R. L., Martins, G. A., Kalachikov, S., Chandele, A., Parish, I. A., Meffre, E., Jacob, J., Calame, K., and Kaech, S. M. (2009). Transcriptional repressor Blimp-1 promotes CD8(+) T cell terminal differentiation and represses the acquisition of central memory $\mathrm{T}$ cell properties. Immunity 31, 296-308.

Sallusto, F., Geginat, J., and Lanzavecchia, A. (2004). Central memory and effector memory T cell subsets: function, generation, and maintenance. Annu. Rev. Immunol. 22, 745-763.

Sallusto, F., Lenig, D., Forster, R., Lipp, M., and Lanzavecchia, A. (1999). Two subsets of memory T lymphocytes with distinct homing potentials and effector functions. Nature 401, 708-712.

Sarkar, J. K., Mitra, A. C., and Mukherjee, M. K. (1975). The minimum protective level of antibodies in smallpox. Bull. World Health Organ. 52, 307-311.

Sarkar, S., Kalia, V., Haining, W. N., Konieczny, B. T., Subramaniam, S., and Ahmed, R. (2008). Functional and genomic profiling of effector $\mathrm{CD} 8 \mathrm{~T}$ cell subsets with distinct memory fates. J. Exp. Med. 205, 625-640.

Schenk, A. D., Gorbacheva, V., Rabant, M., Fairchild, R. L., and Valujskikh, A. (2009). Effector functions of donor-reactive CD8 memory T cells are dependent on ICOS induced during division in cardiac grafts. Am. J. Transplant. 9, 64-73.

Schenk, A. D., Nozaki, T., Rabant, M., Valujskikh, A., and Fairchild, R. L. (2008). Donor-reactive CD8 memory $\mathrm{T}$ cells infiltrate cardiac allografts within 24-h posttransplant in naive recipients. Am. J. Transplant. 8, 1652-1661.

Seder, R. A., Darrah, P. A., and Roederer, M. (2008). T-cell quality in memory and protection: implications for vaccine design. Nat. Rev. Immunol. 8, 247-258.

Sener, A., Tang, A. L., and Farber, D. L. (2009). Memory T-cell predominance following T-cell depletional therapy derives from homeostatic expansion of naive T cells. Am. J. Transplant. 9, 2615-2623.

Setoguchi, K., Schenk, A., Ishii, D. Tanabe, K., and Fairchild, R. L. (2009). Anti-lymphocyte functionassociated antigen-1 (LFA-1) monoclonal antibody prevents graftinfiltrating CD8 memory $\mathrm{T}$ cells early post-transplant. Am. J. Transplant. 9, 209.

Shin, H., Blackburn, S. D., Intlekofer, A. M., Kao, C., Angelosanto, J. M., Reiner, S. L., and Wherry, E. J. (2009). A role for the transcriptional repressor Blimp-1 in $\mathrm{CD} 8(+) \mathrm{T}$ cell exhaustion during chronic viral infection. Immunity 31, 309-320.

Sloan-Lancaster, J., and Allen, P. M. (1996). Altered peptide ligandinduced partial $\mathrm{T}$ cell activation: molecular mechanisms and role in $\mathrm{T}$ cell biology. Annu. Rev. Immunol. 14, 1-27.

Sprent, J., Cho, J. H., Boyman, O., and Surh, C. D. (2008). T cell homeostasis. Immunol. Cell Biol. 86, 312-319.

Stapler, D., Lee, E. D., Selvaraj, S. A. Evans, A. G., Kean, L. S., Speck, S. H., Larsen, C. P., and Gangappa, S. (2008). Expansion of effector memory TCR V\{beta $4+C D 8+\mathrm{T}$ cells is associated with latent infectionmediated resistance to transplantation tolerance. J. Immunol. 180 3190-3200.

Suresh, M., Whitmire, J. K., Harrington, L. E., Larsen, C. P., Pearson, T. C., Altman, J. D., and Ahmed, R. (2001). Role of CD28-B7 interactions in generation and maintenance of CD8 T cell memory. J. Immunol. 167, 5565-5573.

Sykes, M. (2001). Mixed chimerism and transplant tolerance. Immunity 14, 417-424.

Sykes, M., and Sachs, D. H. (1988). Mixed allogeneic chimerism as an approach to transplantation tolerance. Immunol. Today 9, 23-27.

Sykes, M., Szot, G. L., Swenson, K. A., and Pearson, D. A. (1997). Induction of high levels of allogeneic hematopoietic reconstitution and donor-specific tolerance without myelosuppressive conditioning. Nat. Med. 3, 783-787.

Theien, B. E., Vanderlugt, C. L., Eagar, T. N., Nickerson-Nutter, C., Nazareno, R., Kuchroo, V. K., and Miller, S. D. (2001). Discordant effects of anti-VLA-4 treatment before and after onset of relapsing experimental autoimmune encephalomyelitis. J. Clin. Invest. 107, 995-1006.

Thomson, A. W., Turnquist, H. R., and Raimondi, G. (2009). Immunoregulatory functions of mTOR inhibition. Nat. Rev. Immunol. 9, 324-337.

Turgeon, N. A., Avila, J. G., Cano, J. A., Hutchinson, J. J., Badell, I. R., Page, A. J., Adams, A. B., Sears, M. H., Bowen, P. H., Kirk, A. D., Pearson, T. C., and Larsen, C. P. (2010). Experience with a novel efalizumabbased immunosuppressive regimen to facilitate single donor islet cell transplantation. Am. J. Transplant. 10, 2082-2091.

Umetsu, D. T., Yunis, E. J., Matsui, Y., Jabara, H. H., and Geha, R. S. (1985). HLA-DR-4-associated alloreactivity of an HLA-DR-3-restricted human tetanus toxoid-specific $\mathrm{T}$ cell clone: inhibition of both reactivities by an alloantiserum. Eur. J. Immunol. 15, 356-361.

Valujskikh, A., Pantenburg, B., and Heeger, P. S. (2002). Primed allospecific $\mathrm{T}$ cells prevent the effects of costimulatory blockade on prolonged cardiac allograft survival in mice. Am. J. Transplant. 2, 501-509.

van Halteren, A. G., Jankowska-Gan, E., Joosten, A., Blokland, E., Pool, J., Brand, A., Burlingham, W. J., and Goulmy, E. (2009). Naturally acquired tolerance and sensitization to minor histocompatibility antigens in healthy family members. Blood 114, 2263-2272.

Vincenti, F., Charpentier, B., Vanrenterghem, Y., Rostaing, L., Bresnahan, B., Darji, P., Massari, P., Mondragon-Ramirez, G. A., Agarwal, M., Russo, G. D., Lin, C.-S., Garg, P., and Larsen, C. P. (2010). A phase III study of belatacept-based immunosuppression regimens versus cyclosporine in renal transplant recipients (BENEFIT study). Am. J. Transplant. 10, 535-546.

Vincenti, F., Larsen, C., Durrbach, A., Wekerle, T., Nashan, B., Blancho, G., Lang, P., Grinyo, J., Halloran, P. F., Solez, K., Hagerty, D., Levy, E., Zhou, W., Natarajan, K., and Charpentier, B. (2005). Costimulation blockade with belatacept in renal transplantation. N. Engl. J. Med. 353, 770-781.

Vincenti, F., Mendez, R., Pescovitz, M., Rajagopalan, P. R., Wilkinson, A. H., Butt, K., Laskow, D., Slakey, D. P., Lorber, M. I., Garg, J. P. and Garovoy, M. (2007). A phase I/II randomized open-label multicenter trial of efalizumab, a humanized anti-CD11a, anti-LFA-1 in renal transplantation. Am. J. Transplant. 7, 1770-1777. 
Vu, M. D., Clarkson, M. R., Yagita, H., Turka, L. A., Sayegh, M. H., and Li, X. C. (2006). Critical, but conditional, role of OX40 in memory $\mathrm{T}$ cell-mediated rejection. J. Immunol. 176, 1394-1401.

Wang, T., Ahmed, E. B., Chen, L., Xu, J., Tao, J., Wang, C. R., Alegre, M. L., and Chong, A. S. (2010). Infection with the intracellular bacterium, Listeria monocytogenes, overrides established tolerance in a mouse cardiac allograft model. Am. J. Transplant. 10, 1524-1533.

Wang, T., Chen, L., Ahmed, E., Ma, L., Yin, D., Zhou, P., Shen, J., Xu, H., Wang, C. R., Alegre, M. L., and Chong, A. S. (2008). Prevention of allograft tolerance by bacterial infection with Listeria monocytogenes. J. Immunol. 180, 5991-5999.

Weaver, T. A., Charafeddine, A. H., Agarwal, A., Turner, A. P., Russell, M., Leopardi, F. V., Kampen, R. L., Stempora, L., Song, M., Larsen, C. P., and Kirk, A. D. (2009). Alefacept promotes co-stimulation blockade based allograft survival in nonhuman primates. Nat. Med. 15, 746-749.

Welsh, R. M. (2009). Blimp hovers over $\mathrm{T}$ cell immunity. Immunity 31 , 178-180.

Wherry, E. J., and Ahmed, R. (2004). Memory CD8 T-cell differentiation during viral infection. J. Virol. 78, 5535-5545.
Wherry, E. J., Teichgraber, V., Becker, T. C., Masopust, D., Kaech, S. M. Antia, R., von Andrian, U. H., and Ahmed, R. (2003). Lineage relationship and protective immunity of memory CD8 $\mathrm{T}$ cell subsets. Nat. Immunol. 4, 225-234.

Williams, M. A., Onami, T. M., Adams, A. B., Durham, M. M., Pearson, T. C., Ahmed, R., and Larsen, C. P. (2002). Cutting edge: persistent viral infection prevents tolerance induction and escapes immune control following CD28/CD40 blockadebased regimen. J. Immunol. 169, 5387-5391.

Williams, M. A., Tan, J. T., Adams, A. B., Durham, M. M., Shirasugi, N., Whitmire, J. K., Harrington, L. E., Ahmed, R., Pearson, T. C., and Larsen, C. P. (2001). Characterization of virus-mediated inhibition of mixed chimerism and allospecific tolerance. J. Immunol. 167, 4987-4995.

Wojciechowski, S., Jordan, M. B., Zhu, Y., White, J., Zajac, A. J., and Hildeman, D. A. (2006). Bim mediates apoptosis of CD127(lo) effector $\mathrm{T}$ cells and limits $\mathrm{T}$ cell memory. Eur. J. Immunol. 36, 1694-1706.

Woodland, D. L., and Kohlmeier, J. E. (2009). Migration, maintenance and recall of memory $\mathrm{T}$ cells in peripheral tissues. Nat. Rev. Immunol. 9, 153-161.
Wu, Z., Bensinger, S. J., Zhang, J., Chen, C., Yuan, X., Huang, X., Markmann, J. F., Kassaee, A., Rosengard, B. R., Hancock, W. W., Sayegh, M. H., and Turka, L. A. (2004). Homeostatic proliferation is a barrier to transplantation tolerance. Nat. Med. 10, 87-92.

Yamada, A., Salama, A. D., Sho, M. Najafian, N., Ito, T., Forman, J. P., Kewalramani, R., Sandner, S. Harada, H., Clarkson, M. R., Mandelbrot, D. A., Sharpe,A. H., Oshima, H., Yagita, H., Chalasani, G., Lakkis, F. G., Auchincloss, H. Jr., and Sayegh, M. H. (2005). CD70 signaling is critical for CD28-independent CD8+ T cell-mediated alloimmune responses in vivo. J. Immunol. 174 1357-1364.

Yang, J., Brook, M. O., Carvalho-Gaspar, M., Zhang, J., Ramon, H. E., Sayegh, M. H., Wood, K. J., Turka, L. A., and Jones, N. D. (2007). Allograft rejection mediated by memory $\mathrm{T}$ cells is resistant to regulation. Proc. Natl. Acad. Sci. U.S.A. 104, 19954-19959.

Yang, Y., Xu, J., Niu, Y., Bromberg, J. S., and Ding, Y. (2008). T-bet and eomesodermin play critical roles in directing $\mathrm{T}$ cell differentiation to Th1 versus Th17. J. Immunol. 181, 8700-8710.

Zhai, Y., Meng, L., Gao, F., Busuttil, R. W., and Kupiec-Weglinski, J. W. (2002). Allograft rejection by primed/memory CD8 $+\mathrm{T}$ cells is
CD154 blockade resistant: therapeutic implications for sensitized transplant recipients. J. Immunol. 169, 4667-4673.

Zhang, X., Sun, S., Hwang, I., Tough, D. F., and Sprent, J. (1998). Potent and selective stimulation of memory-phenotype CD8+ T cells in vivo by IL-15. Immunity 8 , 591-599.

Conflict of Interest Statement: The authors declare that the research was conducted in the absence of any commercial or financial relationships that could be construed as a potential conflict of interest.

Received: 28 September 2011; accepted: 15 February 2012; published online: 01 March 2012.

Citation: Krummey SM and Ford ML (2012) Heterogeneity within $T$ cell memory: implications for transplant tolerance. Front. Immun. 3:36. doi: 10.3389/fimmu.2012.00036

This article was submitted to Frontiers in Immunological Tolerance, a specialty of Frontiers in Immunology.

Copyright (c) 2012 Krummey and Ford. This is an open-access article distributed under the terms of the Creative Commons Attribution Non Commercial License, which permits non-commercial use, distribution, and reproduction in other forums, provided the original authors and source are credited. 